
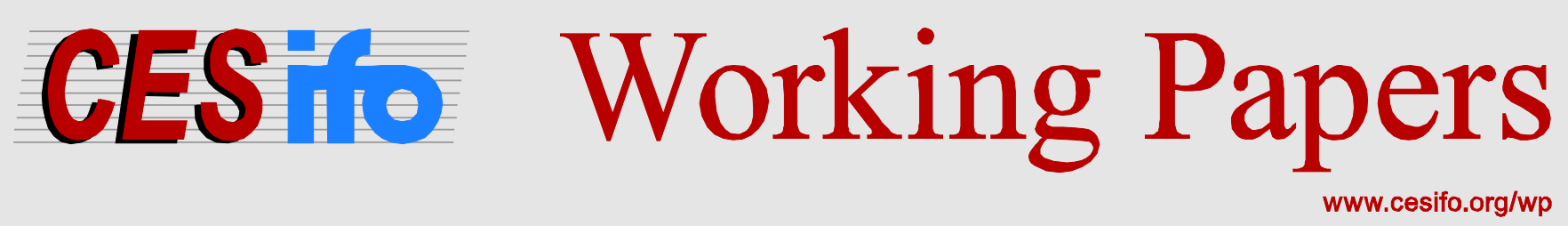

\title{
Effective Tax Rates and Effective Progressivity in a Fiscally Decentralized Country
}

\author{
Marcus Roller \\ Kurt Schmidheiny
}

CESIFO WORKING PAPER NO. 5834

CATEGORY 1: PUBLIC FinANCE

MARCH 2016

An electronic version of the paper may be downloaded

- from the SSRN website:

- from the RePEc website:

- from the CESifo website:

www.SSRN.com

Www.RePEc.org

www.CESifo-group.org/wp 


\title{
Effective Tax Rates and Effective Progressivity in a Fiscally Decentralized Country
}

\begin{abstract}
This paper proposes measures to quantify the effective level and the effective progressivity of taxation in a fiscally decentralized country taking income sorting into account. Using data on the universe of Swiss taxpayers, we find that rich households effectively face significantly lower average and marginal tax rates and lower progressivity than in the benchmark case that does not consider income sorting. This is because high-income households systematically avoid high taxation by locating in low-tax jurisdictions. The results are stronger for singles than for families, indicating that singles are more sensitive to spatial tax differentials than families. Although income tax schedules of the Swiss federation, the 26 cantons and the more than 2,600 municipalities are all strictly progressive, the effectively paid country-wide average tax rate is regressive for households with very high incomes and without children. The proposed measure of the effective average and marginal tax rates also allows us to adequately describe the evolution of the country-wide tax burden over time. We document that about half of the reduction in the tax burden on top incomes between 1975 and 2009 is due to reductions in statutory tax rates and about half to stronger income sorting of the population. Our results also hold when we account for the disutility from housing prices into which tax rates capitalize.
\end{abstract}

JEL-Codes: H710, H730, R230.

Keywords: effective tax rates, progressive taxation, fiscal decentralization, income segregation.

\author{
Marcus Roller \\ Department of Economics \\ University of Basel \\ Peter-Merian-Weg 6 \\ Switzerland - 4002 Basel \\ marcus.roller@unibas.ch
}

\author{
Kurt Schmidheiny* \\ Department of Economics \\ University of Basel \\ Peter-Merian-Weg 6 \\ Switzerland - 4002 Basel \\ kurt.schmidheiny@unibas.ch
}

February 22, 2016

* Also affiliated with the Centre for Economic Policy Research (CEPR) and CESifo.

This paper circulated previously as "Mobility and Progressive Taxation". We thank the Swiss Federal Tax Administration for granting us access to individual-level federal tax data and the Swiss National Science Foundation (Sinergia grants 130648 and 147668) for financial support. We are also grateful to the participants of the CESifo Area Conference on Public Sector Economics, the IIPF Annual Congress, the 9th Meeting of the Urban Economics Association, the 4th Meeting of the European Urban Economics Association, the Sinergia Workshop, the Economic Geography and International Trade Workshop, the Young Swiss Economist Meeting, the SSES Annual Congress, the KOF Research Seminar, the Seminar at Centraal Planbureau, and the Conference on Regional Economics and Public Policy, the ASSA annual meeting 2016. 


\section{Introduction}

Tax schedules can be described by various measures (see Pigou, 1951): effective average tax rates allow comparing the total tax burden, effective marginal tax rates are used in the design of optimal tax schedules (Mirrlees, 1971; Saez, 2001; Conesa and Krueger, 2006) and different progressivity measures inform about the extent to which tax schedules are redistributive (Boadway and Keen, 2000). These measures are designed for a fiscally centralized country with a single country-wide tax schedule. This paper proposes countrywide measures of effective tax rates and effective progressivity for a fiscally decentralized country.

In a fiscally decentralized country, mobile taxpayers face a multitude of different local tax schedules. Different types of taxpayers are typically not uniformly distributed across space. High-income households, for example, are more likely to live in low-tax jurisdictions than low-income households (see e.g. Schmidheiny 2006a, Kleven et al. 2013, Moretti and Wilson 2015, or Akcigit et al. 2015). Different types of households are therefore differently affected by the local tax schedules. High-income households, for example, may be less affected by high tax rates in high-tax jurisdictions simply because they are less likely to live there. We therefore propose to use a country-wide measure of effective average and marginal tax rates that takes the observed income sorting into account. We propose to use a weighted average of the tax rates across jurisdictions, weighted by the actually observed spatial location pattern which depends on the taxpayer type. High tax rates in high-tax jurisdictions will therefore have less weight for the effective country-wide tax rate of high-income households if these households are less likely to be located in high-tax jurisdictions. We call this the effective rate because it is the tax rate that a specific type of taxpayer effectively faces on average in the country. The effective country-wide average tax rate can be consistently estimated by a local polynomial regression using data on the income and location of individual taxpayers.

Following Musgrave and Thin (1948), we focus on three progressivity measures: the change in average rate progression, the liability progression, and the residual income progression. These progressivity measures are also designed for a fiscally centralized country. We apply the same definitions as to our effective country-wide average and marginal tax rates. The resulting country-wide progressivity measures therefore also account for the observed spatial location pattern. We show that important properties of the centralized progressivity measures, such as the consistent classification into progressive and regressive tax systems, also hold for our measures for fiscally decentralized countries.

We apply our proposed country-wide measures of effective tax rates and effective progressivity to local income tax schedules in Switzerland, one of the most fiscally decentralized countries in the world (Brülhart et al., 2015). We use administrative data 
of the universe of Swiss taxpayers (households) between 1975 and 2009. We compare effective country-wide average tax rate with the mean average tax rate that does not account for income sorting as a natural benchmark. We find that the effective countrywide average tax rates are substantially lower than the benchmark rates, in particular for households with very high incomes. This reflects the fact that very high-income households are systematically clustered in low-tax municipalities in Switzerland. The effective marginal tax rates and the effective progressivity are also lower than in the benchmark. We find heterogenous results for different household types: for singles including all Swiss municipalities in 2009, we find that from 100,000 CHF onward, the effective average tax rate is significantly lower than the benchmark. The effective country-wide average tax rate starts flattening at around 500,000 CHF and decreasing after 1M. CHF. However, the progressivity measure is never significantly negative for single households. For married couples without children, our results show that the income tax system even becomes significantly regressive for very high incomes. For families with children the difference between the benchmark and the effective average tax rate is smaller. The proposed measure of the effective average and marginal tax rates also allows us to adequately describe the evolution of the country-wide tax burden over time. We document that about half of the reduction in the tax burden on top incomes between 1975 and 2009 is due to reductions in statutory tax rates and about half to stronger income sorting of the population.

We briefly survey the theoretical literature on income sorting in fiscally decentralized metropolitan areas in section 3. This theoretical literature shows the existence of equilibria in which high-income households tend to live in low-tax jurisdictions with high housing prices while low-income households tend to live in high-tax jurisdictions with low housing prices. The provision of public goods may be higher or lower in low-tax jurisdictions depending on the details of the models. In these models, income sorting is the consequence of systematic location choices of the households based on the local equilibrium tax rates. At the same time, the local tax rates are the result of local votes subject to local budget balance, given the local income distribution in equilibrium. Hence, spatial sorting of taxpayers is theoretically both the cause and the consequence of tax differentials. In this paper, we do not need to take a stance on the causal link between local tax rates and local tax base. We simply take the observed location pattern of different households types to calculate our country-wide measures. However, the theoretical framework clarifies that the observed pattern can indeed be an equilibrium outcome of a micro-founded general equilibrium model.

The theoretical models of income sorting point to the capitalization of tax rates in housing prices. In equilibrium, the financial advantages of low local tax rates are offset by higher local housing prices and a different amount of public services. House price capitalization is empirically well documented (see e.g. Oates 1969, Schmidheiny 2006a, Basten 
et al. 2014 or Morger 2013). In section 8, we develop a simple structural framework that allows us to consider the effect of the disutility from house price capitalization on the effective country-wide progressivity. Applying this approach to the largest Swiss metropolitan area, we show that capitalization leaves our measures of effective progressivity practically unaltered.

This paper is organized as follows: Section 2 discusses the standard measures of tax schedules for a fiscally centralized country and develops their respective counterparts for a fiscally decentralized country. Section 3 reviews the literature on income segregation. Section 4 presents our estimation strategy. Section 5 describes the institutional background in Switzerland while section 6 describes the data. Section 7 presents the results for the year 2009 and the evolution since 1975. Section 8 considers the role of housing prices in our analysis, before section 9 concludes.

\section{Tax Rates and Progressivity}

\subsection{Level of Taxation in a Centralized Country}

Tax schedules are in most countries defined in tax codes and consist of a list of statements relating quantities of payments required from a taxpayer to selected objective conditions (Pigou, 1951). These conditions usually include the gross income and household characteristics. The tax burden is often defined through statutory tax rates applied to taxable income, i.e. gross income minus tax deductions. A meaningful measure of the tax burden has to account for both statutory tax rates as well as tax deductions. The average tax rate, $\operatorname{ATR}(y)$, is defined as the ratio of the tax liability $T(y)$ and gross income $y$. The tax liability $T(y)$ here is itself a function of gross income $y$ :

$$
\operatorname{ATR}(y)=\frac{T(y)}{y}
$$

While the level of taxation influences households' location choice and extensive labour supply decisions, standard literature identifies the marginal tax rate as the relevant determinant of the intensive labour supply decision (see Gruber and Saez (2002), Saez et al. (2012)). The marginal tax rate $\operatorname{MTR}(y)$ is defined as the marginal change in tax liability with gross income:

$$
\operatorname{MTR}(y)=\frac{\partial T(y)}{\partial y}
$$


Table 1: Progressivity Measures

\begin{tabular}{lccc}
\hline \hline & & progressive & regressive \\
\hline Change in Average Rate Progression & $\frac{\partial A T R(y)}{\partial y}$ & $>0$ & $<0$ \\
Liability Progression & $\frac{\partial T(y)}{\partial y} \frac{y}{T(y)}$ & $>1$ & $<1$ \\
Residual Income Progression & $\frac{\partial[y-T(y)]}{\partial y} \frac{y}{[y-T(y)]}$ & $<1$ & $>1$ \\
\hline
\end{tabular}

\subsection{Progressivity in a Centralized Country}

Progressivity measures are based either on the average tax rate or the marginal tax rate (Pigou, 1951): A tax formula is called progressive either if the average rate increases in the tax base (in our case income) or if the marginal tax increases in the tax base. In this paper we use the former concept. Musgrave and Thin (1948) discuss three progressivity measures that are based on this concept of progressivity: the change in average rate progression, the liability progression, and the residual income progression. Table 1 gives an overview and summarizes their main properties.

\section{Change in Average Rate Progression}

The first measure we consider is the change in average rate progression. It is the first derivative of the average tax rate with respect to income:

$$
\frac{\partial A T R(y)}{\partial y}
$$

The change in average rate progression is a function of income $y$ and can therefore vary across income levels. A tax schedule is called progressive (regressive) at income $y$ if the average tax rate increases (decreases) with income, i.e. the first derivative is positive (negative). If the change in average rate progression is positive for all levels of income, the tax schedule is unambiguously redistributive, i.e. the after-tax income distribution lorenz dominates the pre tax income distribution (Jakobsson, 1976).

\section{Liability Progression}

The second measure is called liability progression. It is the elasticity of the tax liability $T(y)$ with respect to income:

$$
\frac{\partial T(y)}{\partial y} \frac{y}{T(y)}
$$

This measure is also a function of income $y$ and might vary across income levels. A tax 
schedule is progressive (regressive) at income $y$ if the the liability progression is greater (smaller) than one. Slitor (1948) calls this measure built-in flexibility because it depicts the sensitivity of individuals' tax yields with respect to changes in their personal income.

\section{Residual Income Progression}

The third measure is called residual income progression. It is the elasticity of the after-tax income $z(y)=y-T(y)$ with respect to income:

$$
\frac{\partial[y-T(y)]}{\partial y} \frac{y}{[y-T(y)]}
$$

Like both previous measures, the residual income progression is a function of the income $y$. A tax schedule is progressive (regressive) at income $y$ if the the liability progression is smaller (greater) than one.

It is straightforward to show that all three progressivity measures are consistent in the classification into progressive and regressive ${ }^{1}$ for strictly positive levels of taxation $(T(y)>$ $0)$ and income $(y>0)$. Thus, if the change in average rate progression indicates that a tax schedule is progressive (regressive) at income $y$, so, too, do the liability progression and the residual income progression. However, the magnitude of progressivity is different across the three measures and the order of the magnitude of progressivity is not necessarily consistent.

For the remainder of the paper we will mainly focus on the change in average rate progression. As we have shown, this is sufficient to classify the tax schedules as progressive or regressive. Furthermore, this measure builds upon the most basic definition of progressivity and is easy to interpret. It enables us to analyze the progressivity not only at income $y$ but also for a certain range of income.

\subsection{Level of Taxation in a Decentralized Country}

In a fiscally decentralized country, the total tax payments to all levels of government depend on the residential jurisdiction because local levels of governments can set different statutory tax rates and deductions. With the standard tool set we can describe these local tax schedules: The average tax rate in jurisdiction $j$ is then defined as:

$$
A T R_{j}(y)=\frac{T_{j}(y)}{y}
$$

where $T_{j}(y)$ is the total tax payment in jurisdiction $j$. This measure is location-specific, i.e. conditional on the jurisdiction $j$. But we seek unconditional country-wide measures of average tax rates, marginal tax rates and progressivity. A first country-wide, i.e.

\footnotetext{
${ }^{1}$ Proof: See appendix B
} 
unconditional, measure of the average tax rate is the mean average tax rate:

$$
\operatorname{MATR}(y) \equiv \sum_{j=1}^{J} P(j) A T R_{j}(y)
$$

Where $P(j)$ is the probability of a taxpayer living in jurisdiction $j$. The local average tax rates are hence weighted by the relative size of the jurisdictions. The mean average tax rate does not take into account that the income distributions may differ systematically across jurisdictions. Hodler and Schmidheiny (2006) therefore propose a country-wide measure that accounts for income sorting of the taxpayers across local jurisdictions:

$$
\operatorname{EATR}(y) \equiv E\left[A T R_{j}(y) \mid y\right]=\sum_{j=1}^{J} P(j \mid y) A T R_{j}(y)
$$

where $P(j \mid y)$ is the conditional probability that a household with gross income $y$ lives in jurisdiction $j$. This measure is the expected average tax rate of a taxpayer with income $y$. Or simply the average tax rate that taxpayers with income $y$ pay in the country. Unlike the mean average tax rate the probability $P(j \mid y)$ is allowed to vary with income. Thus, this measure accounts for differences in the income distributions and therefore for systematic income sorting. We call this measure the effective country-wide average tax rate (EATR).

In the absence of income sorting, i.e. if the local income distributions are the same, $f(y \mid j)=f(y) \forall j=1, \ldots, J$, the effective average tax rate exactly equals the mean average tax $\operatorname{rate}^{2}, \operatorname{EATR}(y)=\sum_{j=1}^{J} P(j) f(y \mid j) / f(y) A T R_{j}(y)=\sum_{j=1}^{J} P(j) A T R_{j}(y)=$ $\operatorname{MATR}(y)$. Hence, the mean average tax rate can be used as a benchmark in the absence of income sorting.

Analogously, we can also define the effective marginal tax rate:

$$
\operatorname{EMTR}(y)=\frac{\partial E\left[T_{j}(y) \mid y\right]}{\partial y}=\sum_{j=1}^{J}\left\{P(j \mid y) M T R_{j}(y)+\frac{\partial P(j \mid y)}{\partial y} T_{j}(y)\right\}
$$

Note that the effective marginal tax rate is not just a weighted mean of the local marginal tax rates, $M T R_{j}(y)$, but also accounts for the change in the location choice probabilities $\partial P(j \mid y) / \partial y$.

Note that our proposed country-wide measure of the effective marginal tax rate is also the relevant marginal tax rate for the behavior of taxpayers in the absence of moving costs. A utility-maximizing taxpayer simultaneously decides on how much to work (intensive

\footnotetext{
${ }^{2}$ This even holds when the local income distributions differ but without systematic relation to the taxation across municipalities. Thus, all deviation of both measures must come from systematic income sorting with respect to taxation.
} 
margin) and where to live (extensive margin). He or she may decide to work a lot, resulting in a higher income, or not so much, resulting in a lower income. Suppose that jurisdiction $\mathrm{A}$ is the optimal (utility-maximizing) location given the low income and jurisdiction $\mathrm{B}$ is the optimal location given the high income. The marginal tax payment for the additional income is then the tax liability at $\mathrm{B}$ for the high income minus the tax liability at $\mathrm{A}$ for the low income. This difference divided by the income difference is the relevant marginal tax rate the taxpayer faces. This marginal tax rate is given by our proposed effective marginal tax rate if the observed location pattern, given income, $P(j \mid y)$, is assumed to be the optimal location pattern.

\subsection{Progressivity in a Decentralized Country}

Applying the definition of the change in average rate progression to the effective average tax rate $\operatorname{EATR}(y)$, we get a measure for the effective progressivity. We define the countrywide change in average rate progression in a fiscally decentralized country as:

$$
\frac{\partial E A T R(y)}{\partial y}=\sum_{j=1}^{J} \frac{\partial P(j \mid y)}{\partial y} A T R_{j}(y)+P(j \mid y) \frac{\partial A T R_{j}(y)}{\partial y}
$$

Thus, an income tax schedule of a fiscally decentralized country is progressive (regressive) whenever the effective country-wide average tax rate increases (decreases). Note that the change in the tax rate comes from two sources: First, the change in the average tax rate at a given jurisdiction, $\partial A T R_{j}(y) / \partial y$. Second, the change in the probability of living in a certain jurisdiction, $\partial P(j \mid y) / \partial y$. Unlike fiscally centralized progressivity measures, this measure is not sufficient to make any statement about utility redistribution (see e.g. Atkinson (1970), Jakobsson (1976), Rothschild and Stiglitz (1973)) because the nominal income redistribution does not directly lead to real income redistribution due to possible capitalization of tax differentials, e.g. into housing prices.

The country-wide liability progression is:

$$
\frac{\partial E T(y)}{\partial y} \frac{y}{E T(y)}=\frac{\partial E A T R(y)}{\partial y} \frac{y}{\operatorname{EATR}(y)}+1
$$

where $E T(y)=E\left[T_{j}(y) \mid y\right]=\sum_{j=1}^{J} P(j \mid y) T_{j}(y)$.

The country-wide residual income progression is defined as follows:

$$
\frac{\partial[y-E T(y)]}{\partial y} \frac{y}{y-E T(y)}=1-\frac{\partial E A T R(y)}{\partial y} \frac{y}{1-\operatorname{EATR}(y)}
$$

It is easy to see that the property of consistent classification into progressive/regressive also holds for these new progressivity measures for decentralized countries. 


\subsection{Statutory vs. Effective Tax Rates}

The literature distinguishes between statutory and effective tax rates. While the former is clearly defined, there is no unique definition of the latter. The statutory tax rate is the percentage rate applied to the respective statutory tax base. In the case of income taxation it is the rate applied to taxable income after all deductions. This tax rate is typically implicitly or explicitly stated in the tax code. Statutory tax rates are insufficient to compare the level of taxation across jurisdictions because the tax base might also vary systematically across jurisdictions (Oates, 1969). This issue is solved by the average tax rate, which is defined as the ratio of income tax liability to gross income before any deductions or benefits. Gross income as a tax base measure and tax liability are both comparable across jurisdictions, and so is the ratio. In principle, transfer payments and means-tested benefits should also be accounted for in order to measure the overall burden. We will abstract from these payments and benefits in our empirical application because they are almost impossible to quantify in Switzerland.

There is no unique definition of effective tax rates in the context of income taxation. ${ }^{3}$ In Mendoza et al. (1994) effective refers to an effective income that contains all sources of income and an effective tax burden that aggregates all different tax burdens from different income sources. This is related to the use of Gouveia and Strauss (1994), who estimate an effective tax function that relates the actual tax burden to economic income. Oates (1969) refers to effective taxation in the context of property taxation as considering the correct tax base which relates to the concept of the average tax rate. Schaltegger et al. (2011) simply call the overall income taxation in Switzerland effective. Thus, there is no unique concept of effective taxation. However, most of them aim to measure a comparable tax burden across jurisdictions.

We define the effective tax rate in fiscally decentralized countries as the ratio of the tax liabilities to gross incomes actually observed. Thus, our definition contains a comparable tax base and tax payments as in Gouveia and Strauss (1994) and Mendoza et al. (1994). In addition, however, our proposed country-wide effective average (EATR) and marginal tax rate $(E M T R)$ takes into account the systematic spatial sorting of the population by income. If, for example, high income households systematically locate in low-tax jurisdictions, then the tax burden of these low-tax jurisdictions will have more weight in the effective tax burden given income.

\footnotetext{
${ }^{3}$ The corporate taxation literature refers to effective tax rates as well. Effective refers to the correct specification of the tax base/corporate income measure (see e.g. Fullerton (1984), Mendoza et al. (1994))
} 


\section{Theoretical Background}

Starting with Tiebout (1956) a large theoretical literature has developed on fiscal decentralization and segregation across jurisdictions. Comprehensive reviews of this literature are provided in Ross and Yinger (1999), Epple and Nechyba (2004) and most recently in Brülhart et al. (2015). Typically, these models consist of a metropolitan area that is divided into several jurisdictions offering different taxation and public good bundles ${ }^{4}$ to mobile households that differ in income. First, households choose their residential jurisdiction and thereafter vote on the the taxation and the public good provision. In most of these models local taxation is a property tax. Early models (see Westhoff (1977), Epple et al. (1984) and Epple and Romer (1991)) provide only equilibria with perfect segregation, i.e. all jurisdictions are exclusively populated with people in a certain income range. Epple and Platt (1998) and Epple and Sieg (1999) add heterogenous household preferences resulting in asymmetric equilibria with imperfect income segregation across jurisdictions. Calabrese et al. (2007) show that adding zoning, i.e. minimum housing size requirements, to the model magnifies the income sorting. Calabrese et al. (2012) perform a welfare analysis and show that the sorting reduces welfare on average and for most of the population.

Only few papers model local income taxation. Goodspeed (1989) finds that high income households sort into jurisdictions with low income tax rates and high housing prices. This result holds in Schmidheiny (2006a), Schmidheiny (2006b) and Hodler and Schmidheiny (2006). Schmidheiny (2006a) introduces progressive income taxation into the model and identifies it as a source of income segregation because the marginal gain of living in low tax jurisdictions is higher for high income households than for low income households. Gravel and Oddou (2014) show that the clear segregation pattern highly depends on assumptions made about the demand function for the public good as well as on the separability of the households' preferences.

The common feature of the above-cited theoretical literature is the existence of segregated equilibria in which high-income households tend to live in low-tax jurisdictions with high housing prices and low-income households tend to live in high-tax jurisdictions with low housing prices. The provision of public goods may be higher or lower in low-tax jurisdictions depending on the details of the models.

Hodler and Schmidheiny (2006) theoretically show that income segregation lowers the country-wide effective progressivity if local jurisdictions can set the level of tax rates but not the entire tax schedule. We generalize this result in Appendix A by allowing that local jurisdictions can set different tax schedules. However, this more general result still relies on the assumption that the order of tax rates across jurisdictions is the same for all income

\footnotetext{
${ }^{4}$ The public good is usually a publicly provided private good.
} 
levels, i.e. a low-tax jurisdiction offers low tax rates compared to other jurisdictions for all levels of income. In reality, local tax schedules may intersect, i.e. some jurisdictions may offer relatively low tax rates for high-income households but relatively high rates for low-income households. It remains therefore an empirical question as to how the observed local tax schedules and the observed income sorting affects the country-wide effective progressivity.

\section{Econometric Method}

This section describes the estimation of the country-wide effective average tax rate function and its progressivity. The effective average tax rate is defined as:

$$
\operatorname{EATR}(y)=E\left[A T R_{j}(y) \mid y\right]=\sum_{j=1}^{J} P(j \mid y) A T R_{j}(y)
$$

Because the gross income $y$ is a continuous variable, the probability of observing a taxpayer with exact income $y$ is zero. Consequently, we cannot directly observe the expected average tax rate. Since the local average tax rates $A T R_{j}(y)$ are observed, Hodler and Schmidheiny (2006) follow the strategy of estimating the probability $P(j \mid y)$ that a taxpayer with income $y$ lives in jurisdiction $j$ using Bayes' rule:

$$
P(j \mid y)=\frac{P(j) f(y \mid j)}{f(y)}
$$

where $P(j)$ is the probability that a taxpayer of any income lives in jurisdiction $j, f(y \mid j)$ is the gross income density in jurisdiction $j$ and $f(y)$ is the country-wide gross income density. Hodler and Schmidheiny (2006) estimate $f(y \mid j)$ and $f(y)$ from data on the municipal income distribution, assuming that income is log-normally distributed both at the municipal and the country level. This approach can easily be implemented as it uses publicly available aggregate data only. However, it rests on highly parametric assumptions about the income distributions.

In this paper, we suggest directly estimating the effective average tax rate $\operatorname{EATR}(y)$ without explicit estimation of $P(j \mid y)$ by a local polynomial regression. In the neighborhood of $\ln \left(y_{0}\right)$ we can approximate the country-wide average tax function with a Taylor 
polynomial of order $p$ :

$$
\begin{aligned}
A T R(\ln (y)) \approx A T R\left(\ln \left(y_{0}\right)\right) & +\frac{\partial A T R\left(\ln \left(y_{0}\right)\right)}{\partial \ln (y)}\left(\ln (y)-\ln \left(y_{0}\right)\right) \\
& +\frac{\frac{\partial^{2} A T R\left(\ln \left(y_{0}\right)\right)}{\partial \ln (y)^{2}}}{2 !}\left(\ln (y)-\ln \left(y_{0}\right)\right)^{2} \\
& +\ldots \\
& +\frac{\frac{\partial^{p} A T R\left(\ln \left(y_{0}\right)\right)}{\partial \ln (y)^{p}}}{p !}\left(\ln (y)-\ln \left(y_{0}\right)\right)^{p}
\end{aligned}
$$

This polynomial can be fitted by the following local weighted least squares estimation:

$$
\min _{\beta} \sum_{i}^{N}\left\{A T R_{i} \sum_{j=0}^{p} \beta_{j}\left(\ln \left(y_{i}\right)-\ln \left(y_{0}\right)\right)^{j}\right\} K_{h}\left(\ln \left(y_{i}\right)-\ln \left(y_{0}\right)\right)
$$

where $K_{h}($.$) are Epanechnikov kernel weights with bandwidth h$, using individual taxpayers' data on gross income ${ }^{5} y_{i}$ and average tax rate $A T R_{i}$. Choosing polynomials of degree $p>0$ allows us to simultaneously estimate the effective average tax rate and the change in average rate progression at a given level of gross income $y_{0}$ :

$$
\begin{aligned}
\left.\widehat{A T R\left(y_{0}\right.}\right) & =\hat{\beta}_{0} \\
\frac{\partial \widehat{A T R_{j}}(y)}{\partial y} & =\frac{\hat{\beta}_{1}}{y_{0}}
\end{aligned}
$$

This method results in consistent ${ }^{6}$ estimates of the effective average tax rate, $\hat{\beta}_{0}$, and the change in average rate progression, $\hat{\beta}_{1} / y_{0}$. This non-parametric approach requires a country-wide sample of individual data with information on the gross income and the tax schedule in the residential jurisdiction. It also requires sufficient observations around each income level $y_{0}$, including top incomes, in order to obtain precise estimates over the entire income range. In fact, we will use the universe of taxpayers in Switzerland.

The benchmark, the mean average tax rate $\operatorname{MATR}(y)$, can easily be calculated as

$$
\widehat{\operatorname{MATR}}(y)=\sum_{j=1}^{J} \widehat{P(j)} A T R_{j}(y)=\sum_{j=1}^{J} \frac{N_{j}}{\sum_{j=1}^{J} N_{j}} A T R_{j}(y)
$$

where the probability $P(j)$ of living in jurisdiction $j$ is estimated using the observed population size of the single jurisdictions $N_{j}$. As discussed above in section 3 , the mean average tax rate is equal to the effective average tax rate in the absence of income sorting.

\footnotetext{
${ }^{5}$ The logarithmic transformation allows us to work with a fixed bandwidth and symmetric kernels for the transformed variable, and therefore growing bandwidths for the original gross income.

${ }^{6}$ The local polynomial regression estimator is generally biased but consistent. Including higher order polynomials reduces this bias, especially at the boundaries (see e.g. Fan and Gijbels (1996)).
} 
Thus, the difference between the two measures must be due to systematic differences in the income distributions. For the effective marginal tax rate one follows exactly the same strategy but using the tax liability $T_{i}$ as dependent variable in eq. (15). The estimator for the effective marginal tax rate is then $\hat{\beta}_{1} / y_{0}$. The liability progression and the residual income progression can be estimated in a similar way.

\section{A Note on Standard Errors}

As we observe the universe of taxpayers in Switzerland, our point estimates of the effective average tax rates can be seen as the true observed values. However, point estimates for top incomes are based on far fewer observations than point estimates for middle incomes. Accordingly, the location of a single taxpayer is influential for the point estimates at top incomes while it is negligible for middle incomes. We therefore report the usual asymptotic standard errors for the local polynomial regression to reflect these differences in the underlying sample sizes. The reported standard errors can be statistically motivated by the fiction that the observed universe of Swiss taxpayers is a mere random draw from a true data generating process with the same distribution as the observed universe.

\section{$5 \quad$ Institutional Background}

Switzerland taxes income on three different levels: federal, cantonal and municipal. This highly decentralized income tax system with its large variation in local tax rates makes Switzerland especially interesting for an empirical application of our set of measures.

The federal state raises tax $T_{f}(y)$ which does not depend on the residential location within Switzerland. The federal tax amount $T_{f}(y)$ is a function of gross income $y$ and household type, i.e. deductions and statutory tax rates depend on household characteristics: Married couples are jointly taxed and treated as a one taxpayer. Tax deductions depend, e.g. on marital status and number of children. There are two different statutory federal tax rates: one for married couples and one for unmarried individuals. The left panel in Figure 1 shows the federal average tax rate, $A T R_{f}(y)=T_{f}(y) / y$, for unmarried individuals in 2009. This average tax rate is the effective rate in the sense that it includes household-type specific deductions, is defined over a comparable tax base and is unconditional on the residential jurisdiction. However, it does not consider means-tested benefits. ${ }^{7}$ The federal average tax rate increases steeply with gross income and is therefore highly progressive for all levels of income.

The 26 cantons set their own income tax schedules $T_{c}(y)$, where $c$ denotes the residential canton which is uniquely identified by the residential municipality $j$. The cantonal tax schedules differ in terms of both deductibles and statutory tax rates. The cantonal

\footnotetext{
${ }^{7}$ see section 2.5 for discussion
} 

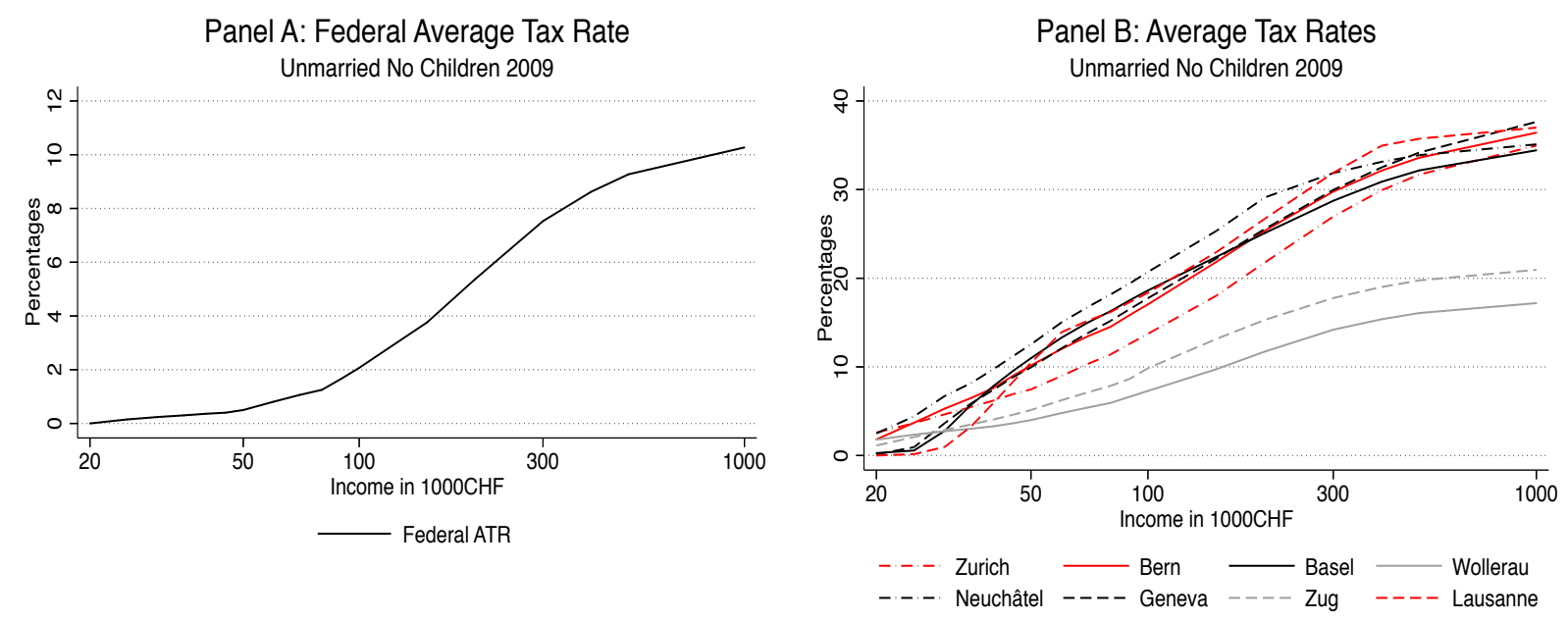

Figure 1: Panel A: Federal average tax rates for unmarried taxpayers in Switzerland in 2009. Panel B: Average tax rates (including federal, cantonal and municipal tax) for unmarried taxpayers in 8 Swiss municipalities in 2009 .

tax schedules are typically less progressive than the federal one. In some cantons, e.g. Obwalden and Uri, it is a flat-rate tax.

The 2,624 municipalities also tax income. The municipal income tax is a multiple of the cantonal tax liability: $M_{j} T_{c}(y)$, i.e. within cantons, municipal tax rates only vary with the tax multiplier $M_{j}{ }^{8}$

The total income tax liability of an individual with gross income $y$ living in municipality $j$ is the sum of the income taxes collected by the three governmental layers:

$$
T_{j}(y)=\left(1+M_{j}\right) T_{c}(y)+T_{f}(y)
$$

The average tax rate in municipality $j$ at gross income $y$ is the ratio of the income tax liability $T_{j}(y)$ to the gross income $y$ :

$$
A T R_{j}(y)=\frac{T_{j}(y)}{y}
$$

The federal and all 26 cantonal tax schedules are progressive, i.e. $\partial A T R_{f}(y) / \partial y>0$ and $\partial A T R_{c}(y) / \partial y>0$. Hence, the combined local tax schedules are also progressive in each municipality, i.e. $\partial A T R_{j}(y) / \partial y>0$.

This tax system results in 2,624 tax schedules in Switzerland. The right panel in Figure1 shows the combined average tax rate, $A T R_{j}(y)=T_{j}(y) / y$, for unmarried individuals in 8 selected municipalities in the year 2009. It illustrates the large variation in

\footnotetext{
${ }^{8}$ There is also a local church tax defined as a multiple of the cantonal tax amount. Church taxes are collected by the government for individuals who are members of the Catholic, Protestant or Jewish community. The geographic borders of the municipalities and the religious communities are typically, but not always, congruent. We add the tax multiplier of the local majority church to the municipal tax multiplier in the empirical study. The church tax is small and does not drive our results.
} 
Table 2: Descriptive Statistics of Individual Gross Income in 2009.

\begin{tabular}{lrrrr}
\hline \hline & \multicolumn{1}{c}{ All } & Unmarried & Married Couple & Married Couple \\
Taxpayers & No Children & No Children & 2 Children \\
\hline N obs. & $2,379,827$ & $1,649,167$ & 427,377 & 303,283 \\
Mean & 75,337 & 56,173 & 114,498 & 125,730 \\
SD & 155,808 & 93,820 & 268,202 & 185,400 \\
\hline Median & 62,198 & 51,382 & 93,179 & 101,531 \\
Top-10\% & 131,649 & 94,870 & 177,590 & 194,793 \\
Top-5\% & 169,246 & 117,394 & 230,891 & 256,930 \\
Top-1\% & 319,446 & 199,575 & 463,273 & 506,930 \\
Top-0.1\% & 962,175 & 556,622 & $1,622,840$ & $1,434,418$ \\
\hline
\end{tabular}

these tax schedules across municipalities, both in level and progressivity. Additionally, it reveals that tax schedules in municipalities located in different cantons can intersect. Thus, a municipality might be a high tax municipality for low incomes and a low tax municipality for high incomes. Section 6 provides more descriptive results regarding the spatial distribution of the tax schedules.

\section{Data}

As described in the methodology section, we need data on taxpayers' gross income and average tax rates. We use administrative data on the universe of all Swiss taxpayers and the universe of Swiss municipalities. We focus on three household types: unmarried taxpayers without children, married taxpayers without children and married taxpayers with children. The following section describes the data set and its construction in detail.

\subsection{Individual Income Data}

We use confidential administrative data on the universe of Swiss taxpayers from the Swiss Federal Tax Administration (ESTV) for the years 1974 to 2009. Note that married couples are treated as one taxpayer in Switzerland. We observe their federal taxable income, their residential location (municipality) and their tax-relevant household characteristics (marital status and number of children that qualify for tax deductions). Federal taxable income is reported income from wages, self-employment, pension benefits, interest, dividends, etc. minus social security contributions and household-type specific deductions for the federal income tax. ${ }^{9}$ We approximate gross income $y_{i}$, i.e. income before social security contributions and tax deductions, for each taxpayer from taxable income and household characteristics, applying the federal tax code (see Appendix C for details).

\footnotetext{
${ }^{9}$ Capital gains are not taxed in Switzerland and therefore not reported as income in our data.
} 


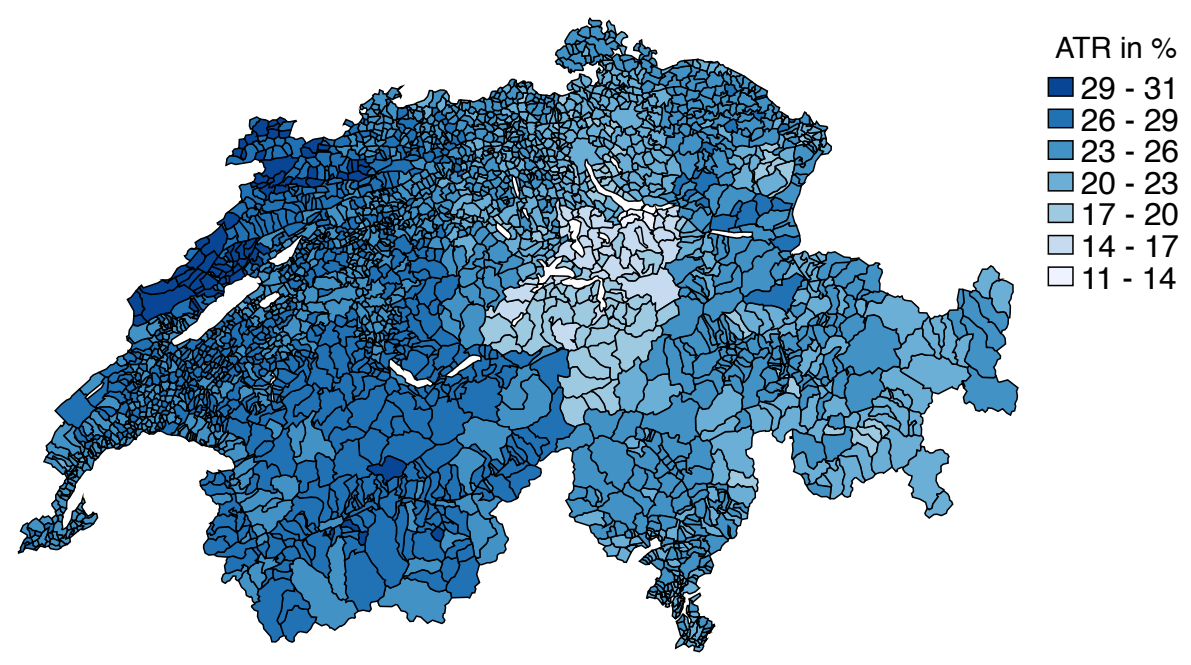

Figure 2: Average tax rates across Swiss municipalities in 2009 for an unmarried taxpayer with top-1\% income. Combined federal, cantonal and municipal tax rates.

In 2009, we observe 1,649,167 single households, 427,377 married couples without children and 303,283 married couples with children. Table 2 reports descriptive statistics for the gross income distribution of these three different types of taxpayers. Unmarried taxpayers have the lowest mean income of the three types and married couples with children the highest. This also holds for all percentiles up to the $99 \%$ percentile.

\subsection{Tax Burden}

The Swiss Federal Tax Administration (ESTV) annually publishes the tax burden for a sample of Swiss municipalities. ${ }^{10}$ The combined cantonal, municipal, and church tax burden as well as the federal tax burden is reported. Tax burdens are reported for different household types (unmarried taxpayer without children, married couple without children, married couple with two underage children, retired married couple) and for different levels of gross income. ${ }^{11}$

The reported tax burden in Swiss Francs (CHF) is calculated using the federal and cantonal tax codes as well as the municipal multipliers. The calculation first subtracts social security contributions as well as federal and canton-specific tax deductions for e.g. underage children and applies the respective statutory tax rates for unmarried and married taxpayers.

For the year 2009, the ESTV reports the tax burden for 813 municipalities. This data

\footnotetext{
${ }^{10}$ Swiss Federal Tax Administration, Steuerbelastung in der Schweiz, Neuchâtel: Swiss Federal Statistical Office. Data for the years before 1996 is only available as scanned images. This data was digitized by Kurt Schmidheiny and his team within the Sinergia Project 130648 founded by the Swiss National Science Foundation.

${ }^{11}$ For example in 2009: CHF 20,000; 25,000; 30,000;35,000;40,000;45,000; 50,000; 60,000; 70,000; 80,$000 ; 90,000 ; 100,000 ; 150,000 ; 200,000 ; 300,000 ; 400,000 ; 500,000 ; 1,000,000$.
} 
Table 3: Average Tax Rates (\%) across Swiss Municipalities in 2009.

\begin{tabular}{llccccc}
\hline \hline & Percentile & Nobs. & Mean & Std. Dev. & Min & Max \\
\hline \multirow{3}{*}{ Unmarried } & Median & 2,624 & 9.95 & 1.49 & 4.06 & 13.7 \\
& Top-20\% & 2,624 & 13.93 & 1.81 & 5.7 & 18.81 \\
& Top-10\% & 2,624 & 16.19 & 1.94 & 6.93 & 21.42 \\
& Top-1\% & 2,624 & 24.5 & 2.59 & 11.66 & 30.82 \\
\hline \multirow{3}{*}{ Married } & Median & 2,624 & 10.94 & 1.79 & 4.79 & 15.37 \\
No Children & Top-20\% & 2,624 & 15.04 & 1.83 & 6.94 & 19.76 \\
& Top-10\% & 2,624 & 18.49 & 1.99 & 9.03 & 23.69 \\
& Top-1\% & 2,624 & 29.46 & 2.73 & 15.28 & 34.97 \\
\hline \multirow{3}{*}{ Married } & Median & 2,624 & 8.25 & 1.74 & 3.23 & 11.89 \\
& Top-20\% & 2,624 & 12.95 & 1.79 & 5.93 & 17.61 \\
& Top-10\% & 2,624 & 17.05 & 1.91 & 8.42 & 22.29 \\
& Top-1\% & 2,624 & 28.89 & 2.66 & 15.01 & 34.55 \\
\hline
\end{tabular}

is extended to all 2,624 Swiss municipalities by collecting tax multipliers for all municipalities (see Parchet (2014) for details). Table 3 reports mean and standard deviation for selected household types (unmarried, married two children) and incomes (median, top-20\%, top-10\%, top-1\%). Figure 2 shows the spatial variation of average tax rates for unmarried taxpayers with top-1\% income. Both descriptive statistics and the map document substantial variation in tax rates across Swiss municipalities. For an unmarried taxpayer with median income, for example, the tax burden in the highest-tax municipality is three times that of the lowest-tax municipality.

\subsection{Individual Tax Rates}

For our analysis we need the individual average tax rates and not only those at the grid points provided by the ESTV. The data on individual taxpayers contains only the tax information needed for the federal income tax, i.e. it does not contain any information about the cantonal or municipal taxes. Thus, we have to calculate them by using the data on the tax burden in their residential municipalities. We calculate the individual tax burden, $T_{i}\left(y_{i}\right)$, for each taxpayer using the approximated gross income, $y_{i}$, and the data on the combined tax burden for different household types and income levels in all Swiss municipalities. We interpolate the tax burden for income levels which are not reported in our tax burden data (see Appendix $\mathrm{C}$ for details). The average tax rate for each taxpayer in our individual data is simply $A T R_{i}=T_{i}\left(y_{i}\right) / y_{i}$.

\subsection{Income Sorting}

Median income differs substantially across Swiss municipalities. Figure 3 plots the mean incomes of all Swiss municipalities against the average tax rate of an unmarried tax 


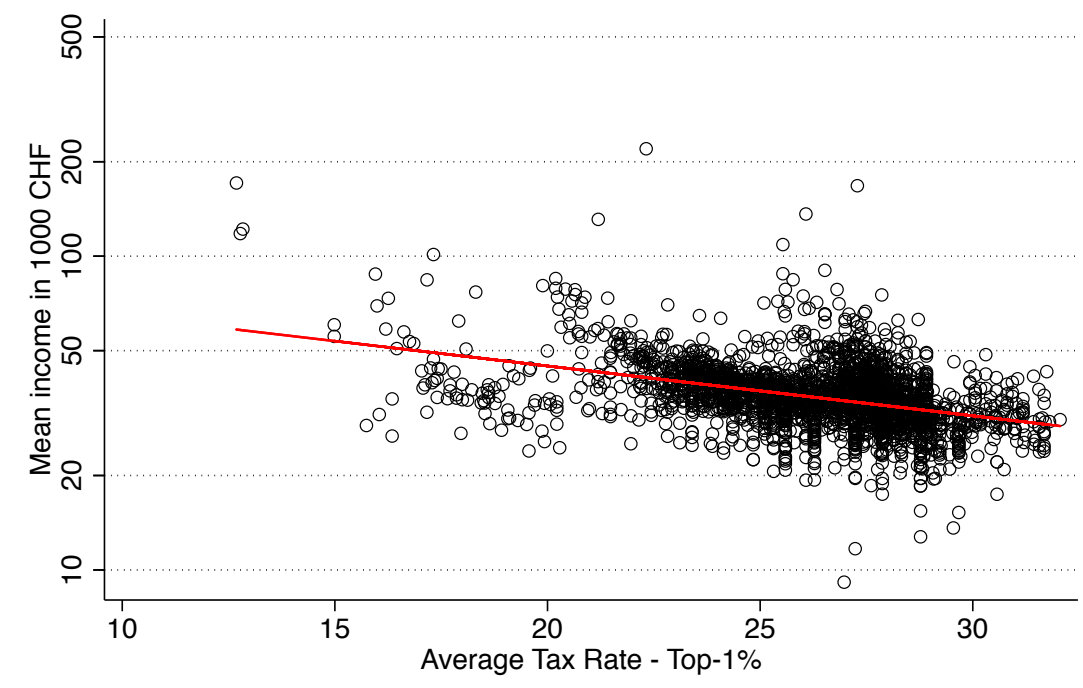

Figure 3: Mean income and average tax rate for an unmarried taxpayer with top-1\% income across Swiss municipalities in 2009.

payer with top-1\% income. The solid red line represents the fitted value of a simple OLS regression of the logarithm of the mean income on this average tax rate. The slope coefficient is -0.037 and highly significant. Thus, our data suggests a strong sorting of high income households into low tax municipalities. This is consistent with the literature, as mentioned in section 3. Consequently, we expect the effective average tax rates to differ from the mean average tax rate.

\section{Results}

We first report country-wide results for the whole of Switzerland for the year 2009 in subsection 7.1. We then restrict our analysis to a single metropolitan area in Subsection 7.2. The historic development from 1974 to 2009 is shown in Subsection 7.3.

\section{$7.1 \quad$ Switzerland}

The left panel of Figure 4 presents the results from the non-parametric estimation of the effective average tax rate for unmarried taxpayers in 2009. The solid red line is the country-wide effective average tax rate $\operatorname{EATR}(y)$. The grey band is the pointwise $95 \%$ confidence interval. The black dashed lines represent the average tax rate in the municipality with the highest and lowest tax burden at the given gross income, respectively. The red dash-dotted line is our benchmark, the mean average tax rate $M A T R(y)$. It monotonically increases with gross income. This reflects the fact that the combined federal, cantonal and municipal tax schedules monotonically increase in each Swiss municipality, as discussed in Section 5. 

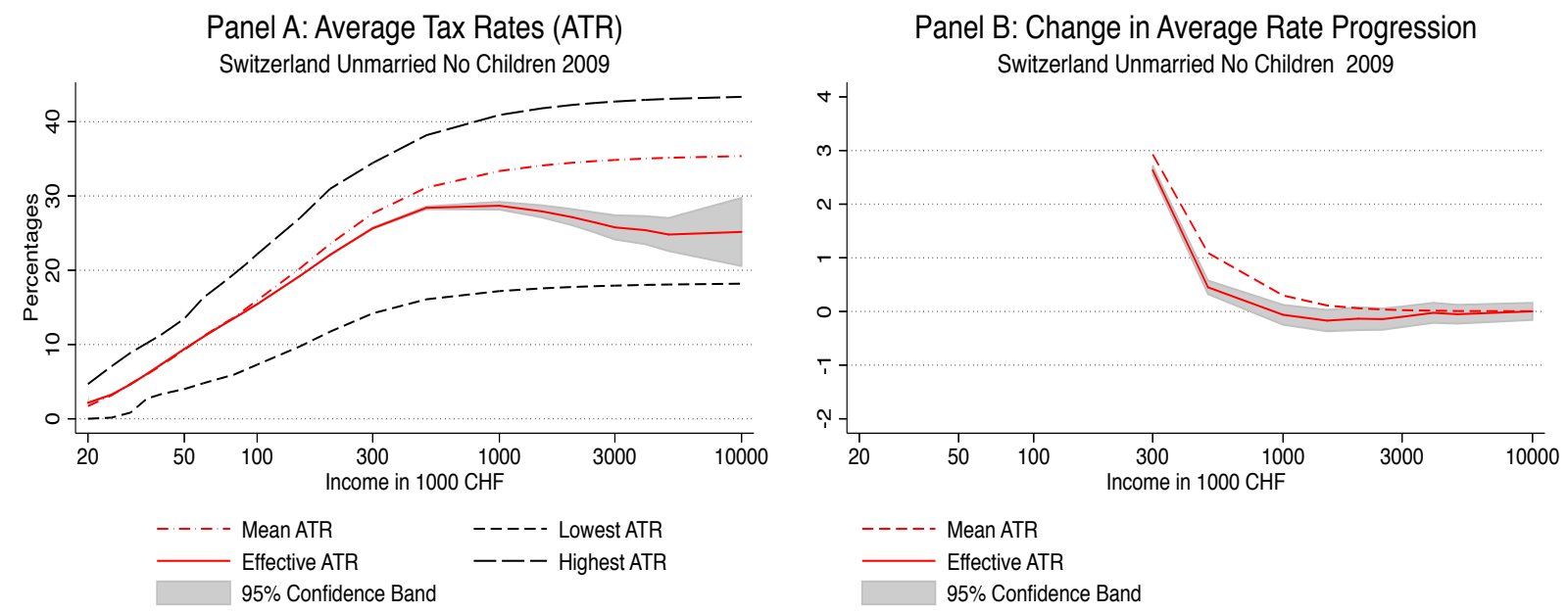

Figure 4: Country-wide average tax rate and progressivity of unmarried taxpayers. 1,649,167 observations, local polynomial regression (order 3) with Epanechnikov kernel and half-logbandwidth 0.343 . Change in average rate progression multiplied by 100,000.

Starting from 100,000 CHF (approximately 96,000 USD end of 2009), the effective average tax rate is significantly lower than the mean average tax rate. The gap increases constantly up to about ten percentage points for an income of 10M. CHF. This difference arises from income sorting. Thus, taxpayers with incomes above 100,000 CHF live systematically in municipalities with comparably low tax rates. Starting from 1M. CHF, the effective average tax rate even decreases. Also, our estimates for the effective countrywide change in average rate progression, shown in the right panel of Figure 4, are lower for high incomes than the benchmark and negative for incomes above 1M. CHF, which would indicate that the tax system in this range is even regressive. However, all negative estimates are not significantly different from zero. For incomes above 3M. CHF, there is not even a significant difference between the effective average tax rate and the benchmark anymore. This is due to the fact that marginal tax rates are constant in all cantons as of an income of around 500,000 CHF, which gives a progressivity of zero in the limit by construction.

The estimated effective progressivity shown in the right panel is a local estimate in the sense that it is the marginal change of the effective average tax rate at a given level of gross income. The term progressivity can in principle also be applied to discrete changes of the effective average tax rate. The left panel of Figure 4 shows that the confidence band of the effective average tax rates falls after an income of about $1 \mathrm{M}$. CHF, indicating that the effective country-wide tax schedule is in fact regressive for large changes in income. Table 4 reports statistical tests for discrete changes in income from 500,000 CHF to incomes above 1M. CHF. Moving from e.g. 500,000 CHF gross income to 5M. CHF significantly $(p<0.05)$ reduces the effective average tax rate by 3.6 percentage points from 28.4 to 24.8 percent for unmarried taxpayers. The results for the married taxpayers 
Table 4: Differences between effective average tax rates (EATR) at different incomes in 2009.

\begin{tabular}{lccc}
\hline \hline & Unmarried & Married & Married \\
Income & No Children & No Children & 2 Children \\
\hline Difference of EATR compared to EATR at 500,000 CHF & - \\
1,000,000 CHF & 0.279 & - & - \\
& $(0.277)$ & - & $4.497^{* * *}$ \\
2,000 '000 CHF & $-1.266^{* *}$ & $2.891^{* * *}$ & $(0.277)$ \\
& $(0.559)$ & $(0.229)$ & $4.280^{* * *}$ \\
3'000,000 CHF & $-2.638^{* * *}$ & $2.190^{* * *}$ & $(0.495)$ \\
& $(0.836)$ & $(0.365)$ & $3.796^{* * *}$ \\
$5,000,000 \mathrm{CHF}$ & $-3.601^{* * *}$ & $1.822^{* * *}$ & $(0.824)$ \\
& $(1.138)$ & $(0.660)$ & 3.687 \\
$10,000,000 \mathrm{CHF}$ & -3.253 & -0.819 & $(1.750)$ \\
& $(2.339)$ & $(1.340)$ & $26.93 \%$ \\
\hline EATR at 500,000 CHF & $28.41 \%$ & $26.96 \%$ & \\
\hline
\end{tabular}

Standard Errors in Parentheses. Significance levels: ${ }^{*} p<0.10,{ }^{* *} p<0.05,{ }^{* * *} p<0.01$.

read as follows: At all income levels from 500,000 CHF households pay significantly higher tax rates up to an income of 5M. CHF. Households with an income of 10M. CHF do not face significantly higher tax rates than households with an income of 500,000 CHF.

The results for married couples without children are similar, as Figure 5 shows. The deviation of the effective average tax rate from the mean average tax rate starts at about 150,000 CHF and also increases up to ten percentage points. The progressivity for high incomes is also significantly lower. In the range of $2 \mathrm{M}$. up to $3 \mathrm{M}$. CHF it becomes even slightly but significantly negative.
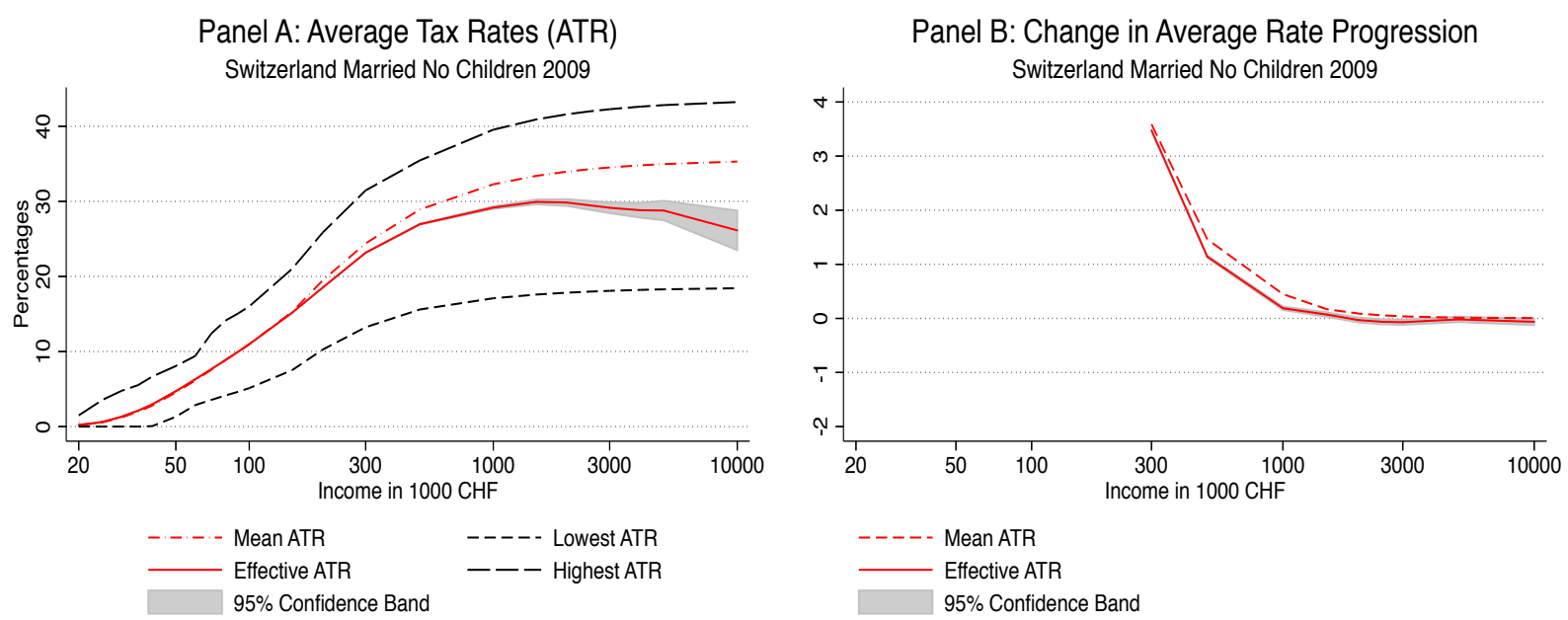

Figure 5: Country-wide average tax rate and progressivity of married couples without children. 427,377 observations, local polynomial regression (order 3) with Epanechnikov kernel and halflog-bandwidth 0.571 . Change in average rate progression multiplied by 100,000. 
Panel A: Average Tax Rates (ATR) Switzerland Married 2 Children 2009

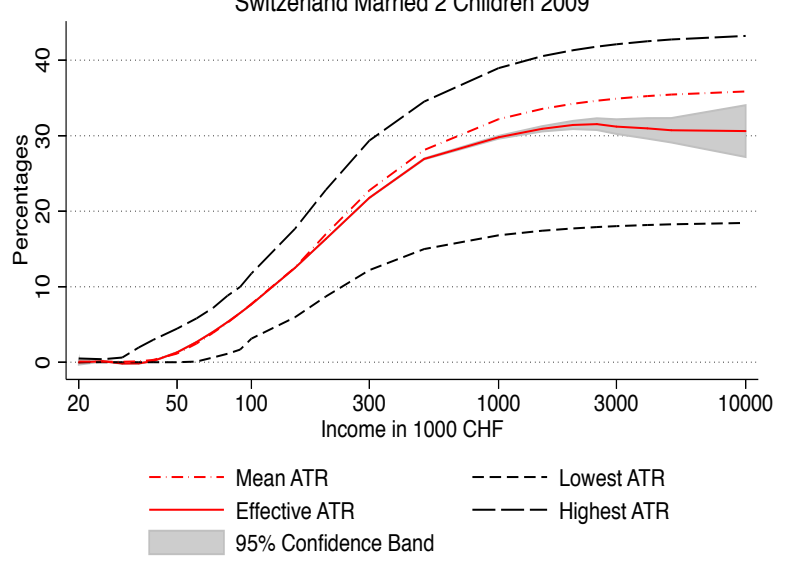

Panel B: Change in Average Rate Progression

Switzerland Married 2 Children 2009

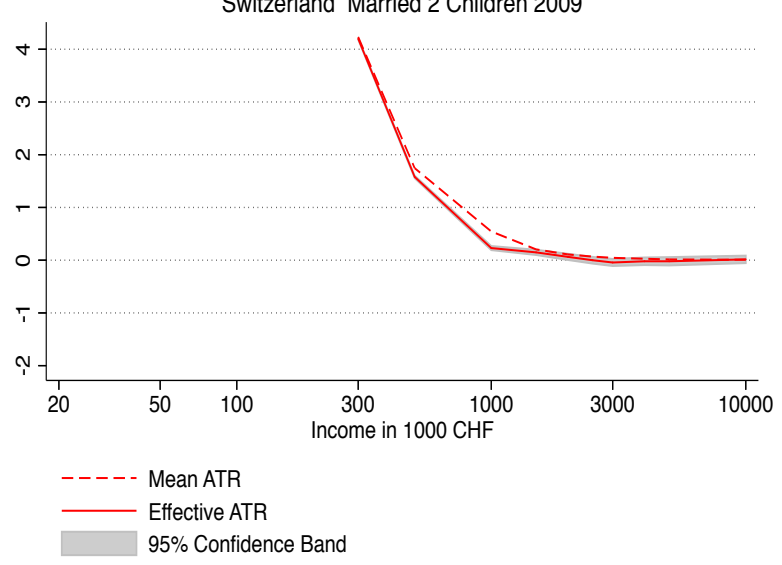

Figure 6: Country-wide average tax rate and progressivity of married couples with two children. 303,283 observations, local polynomial regression (order 3) with Epanechnikov kernel and halflog-bandwidth 0.516. Change in average rate progression multiplied by 100,000.

For families with two children the results differ from the previous types. Figure 6 depicts these results. We immediately see that the difference between the effective tax rate and the benchmark as well as the difference between the effective progressivity and its benchmark are smaller than in the previous cases. The effective average tax rate is only significantly lower than the mean average tax rate for incomes above 200,000 $\mathrm{CHF}$ and the difference only reaches six percentage points for households with an annual income of 10M. CHF. The progressivity is also significantly lower, but the difference of the effective progressivity to its benchmark is smaller than for unmarried taxpayers and married couples without children. These results are not surprising since families with children are likely to differ from the other types in their preferences regarding location choice. Unlike the other household types, they care, e.g., about the quality of schooling (Epple et al. (2012)). In Switzerland, elementary schooling is indeed exclusive and only accessible for children living within a school district. Black (1999) shows that parents are indeed willing to pay for higher schooling quality. Bayer et al. (2007) also find the same result but of minor size. They point out that this difference is explained by neighborhood quality effects. Following Basten et al. (2014) this is likely to be the case in Switzerland as well because schools are to a large extent financed and regulated ${ }^{12}$ by the cantons. Thus, we would not expect that school provision drives our results but rather neighborhood composition effects. Thus, families might care a lot about their peers and their children's peers in school, which affects ex post school quality. Bayer and McMillan (2012) also find that families care more about the availability of large houses compared to households without children. Overall, the differences in our results between households with and without children are more likely to be driven by housing availability and peer effects than

\footnotetext{
${ }^{12}$ e.g. class sizes.
} 
Panel A: Marginal Tax Rate (MTR)

Switzerland Unmarried No Children 2009

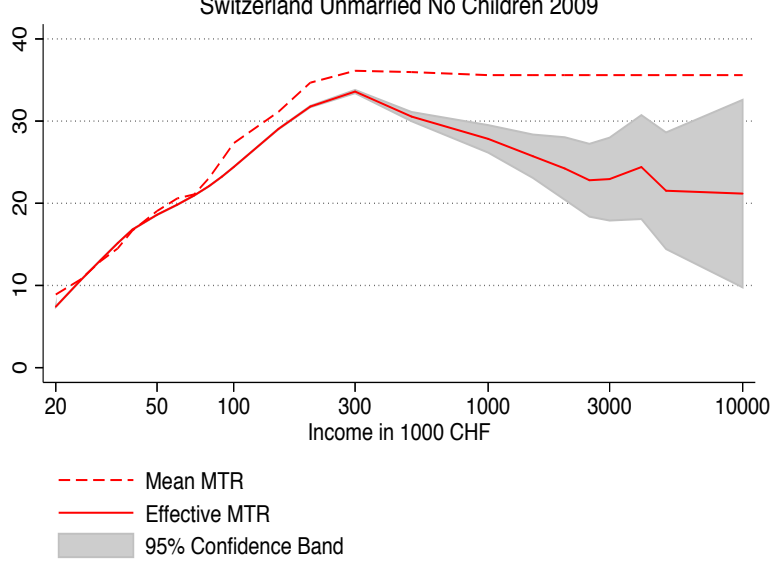

Panel A: Marginal Tax Rate (MTR)

Switzerland Married No Children 2009

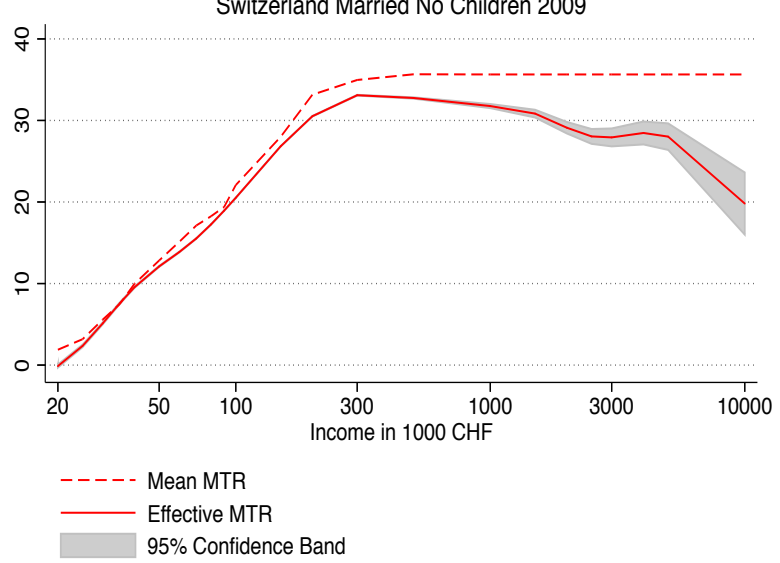

Figure 7: Country-wide marginal tax rate in 2009. Local polynomial regression (order 3) with Epanechnikov kernel. Unmarried taxpayers: 1,649,167 observations, half-log-bandwidth 0.343. Married couples without children: 427,377 observations, half-log-bandwidth 0.571.

differences in the quality of supplied schooling.

We also estimate the effective marginal tax rate, $\operatorname{EMTR}(y)$, using a non-parametric regression. Figure 7 presents the results of the estimations for unmarried taxpayers (left panel) and for married couples without children (right panel). For unmarried taxpayers, the effective marginal tax rate is lower than the mean marginal tax rate (benchmark) for incomes above 80,000 CHF. For married couples the deviations does not start before 100,000 CHF. While for both household types the difference between the effective and the mean marginal tax rate is comparably small for incomes below 300,000 CHF, it starts increasing considerably for higher incomes. This increase is driven by a decrease in the effective marginal tax rate, while the mean marginal tax rates for high incomes are almost
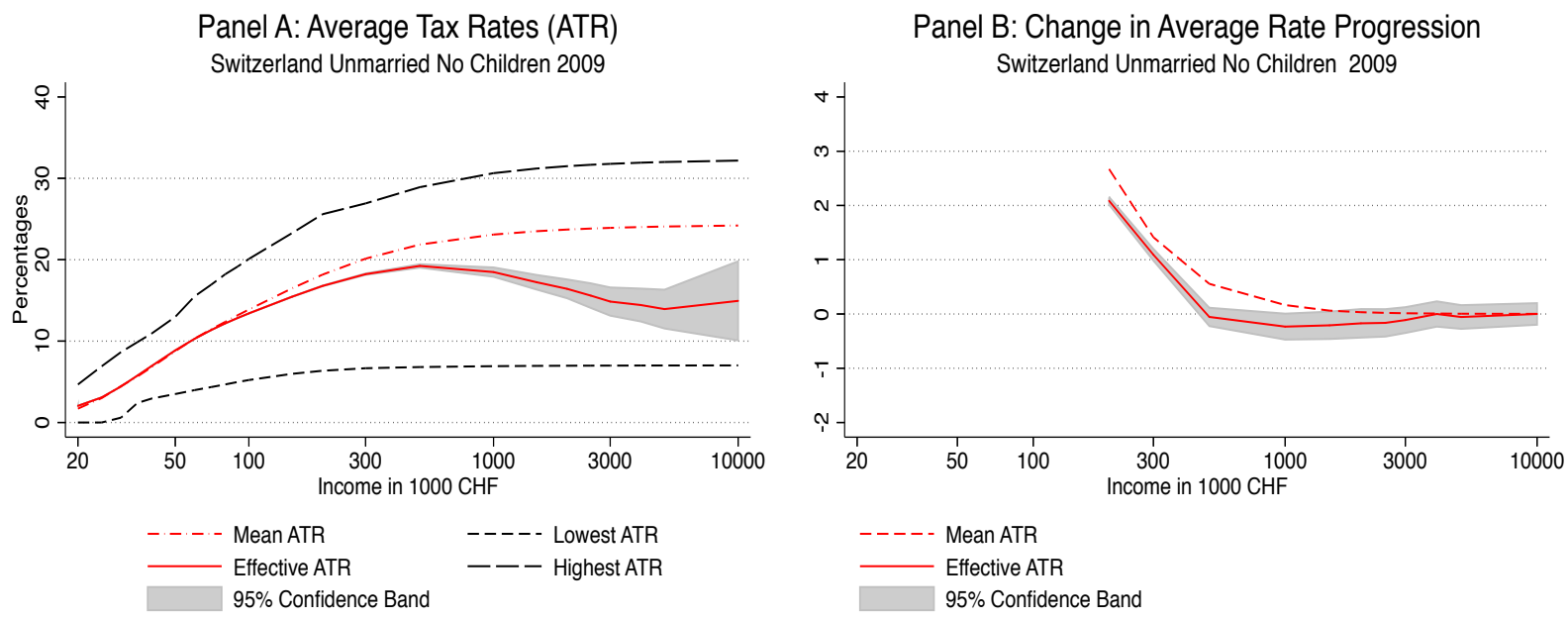

Figure 8: Country-wide average tax rate and progressivity of only sub-central (cantonal and municipal) income taxes for unmarried taxpayers. 1,649,167 observations, local polynomial regression (order 3) with Epanechnikov kernel and half-log-bandwidth 0.299. Change in average rate progression multiplied by 100,000 . 


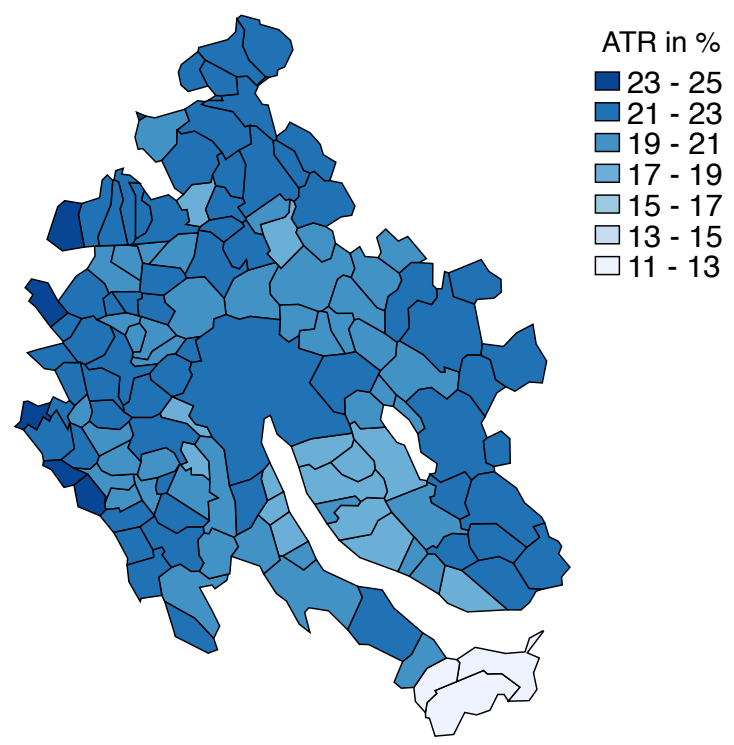

Figure 9: Average tax rates for an unmarried taxpayer with top-1\% income in the Zurich metropolitan area in 2009. Combined federal, cantonal and municipal tax rates.

constant in both cases. The latter is due to the fact that the statutory marginal tax rates are also constant for most of the cantons in this income range. Similar results but of smaller size also hold for families with two children.

For all three household types, the effective average tax rate, the effective marginal tax rate and the effective progressivity are lower than the benchmark that does not account for income sorting. We even find that for unmarried taxpayers, the income tax system becomes regressive for a certain range of high incomes.

The results so far include the highly progressive federal income tax, which is constant across the country. In order to assess the role of the federal tax, we repeat the estimation considering only sub-central, i.e. cantonal and municipal taxes. Figure 8 shows these results. Just considering local tax rate differentials strengthens our previous findings: the effective average tax rates stop rising after an income of 500,000 CHF and fall after about 1M. CHF.

\subsection{Zurich Metropolitan Area}

Theoretical models of spatial income sorting from local tax rate differentials typically model a single city or metropolitan area (see Section 3). In such a setting it is reasonable to assume that households earn some given income at some workplace (e.g. the central business district) and choose their residential location within the city given their income. However, this assumption is not reasonable when studying a whole country, because choosing a metropolitan area or region within the country will likely affect the workplace and hence income. In order to get our empirical results closer to the theoretical motivation, we repeat the analysis considering only municipalities within one metropoli- 
Panel A: Average Tax Rates (ATR)

Zurich Unmarried No Children 2009

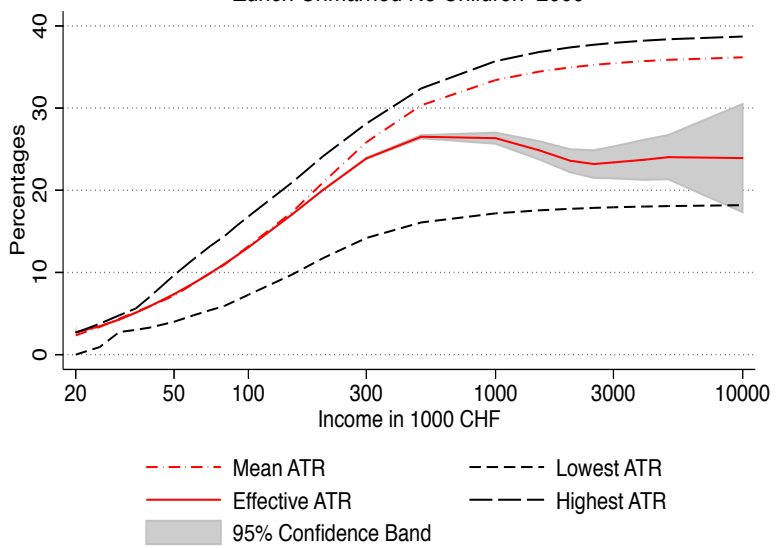

Panel B: Change in Average Rate Progression

Zurich Unmarried No Children 2009

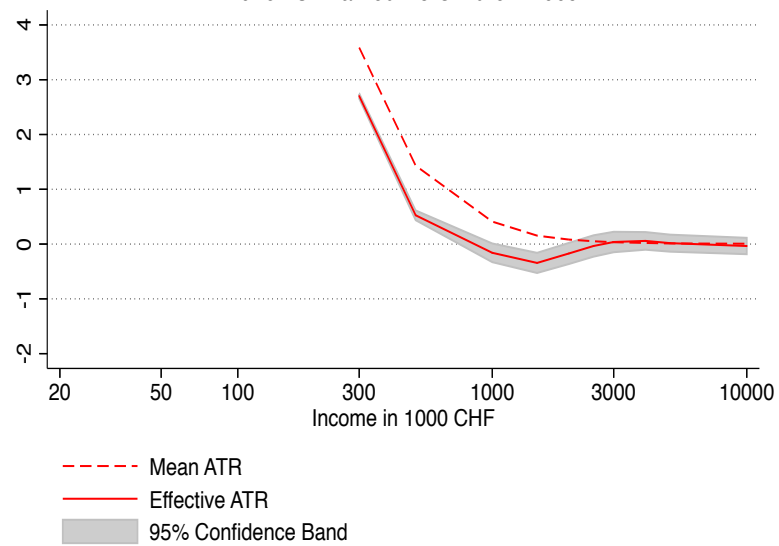

Figure 10: Average tax rate and progressivity of unmarried taxpayers in the Zurich metropolitan area in 2009. 286,831 observations, local polynomial regression (order 3) with Epanechnikov kernel and half-log-bandwidth 0.459 . Change in average rate progression multiplied by 100,000.
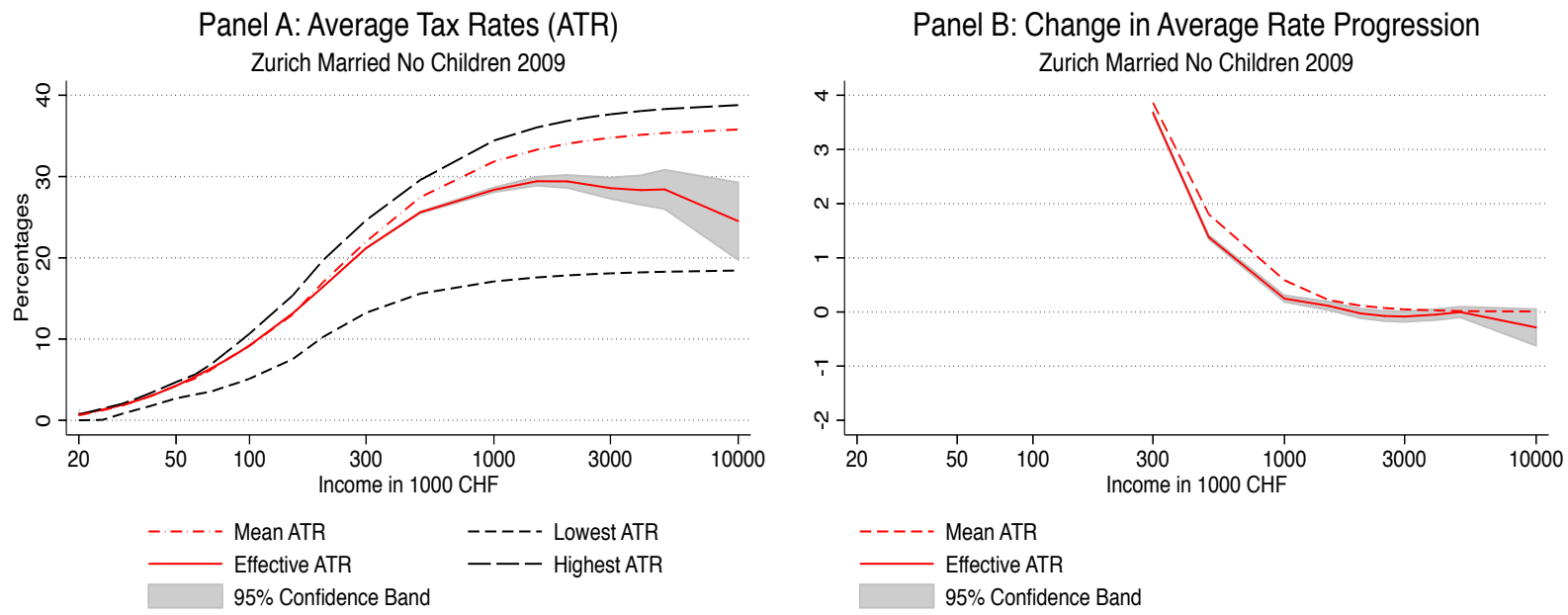

Figure 11: Average tax rate and progressivity of married couples without children in the Zurich metropolitan area in 2009. 66,721 observations, local polynomial regression (order 3) with Epanechnikov kernel and half-log-bandwidth 0.534. Change in average rate progression multiplied by 100,000 .

tan area. ${ }^{13}$ We choose the Zurich metropolitan area, the economically most important area in Switzerland. ${ }^{14}$

Even within this smaller area, we observe large tax differential as Figure 9 indicates. Because the tax differentials are comparable to those of Switzerland and the mobility within a smaller area should be higher than across Switzerland, we expect the effects within this metropolitan area to be larger than for the entire country.

Figure 10 presents the results of the estimations for single households. We observe an increasing gap between the lowest and highest possible average tax rates up to 20

\footnotetext{
${ }^{13}$ Note that our empirical results for the entire country are valid but only harder to explain theoretically.

${ }^{14}$ The metropolitan area is defined by the Swiss Federal Statistical Office. Note that it is not congruent with the canton of Zurich.
} 
Panel A: Average Tax Rates (ATR) Zurich Married 2 Children 2009

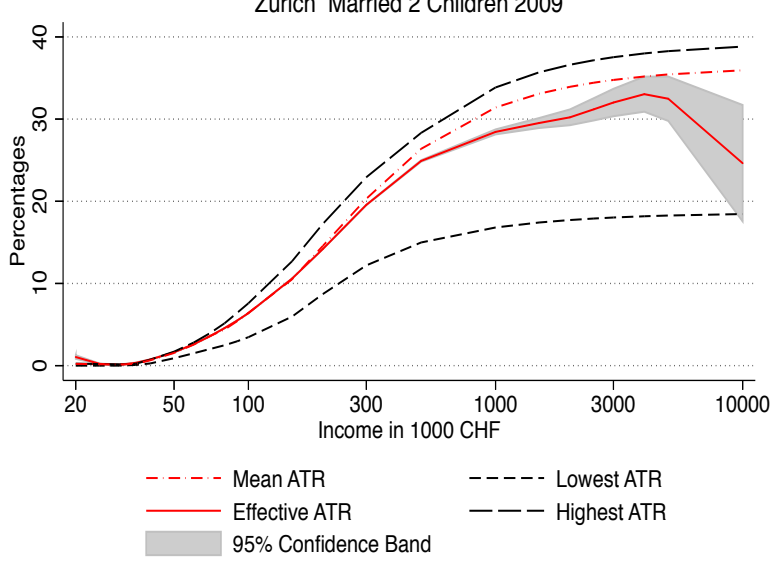

Panel B: Change in Average Rate Progression

Zurich Married 2 Children 2009

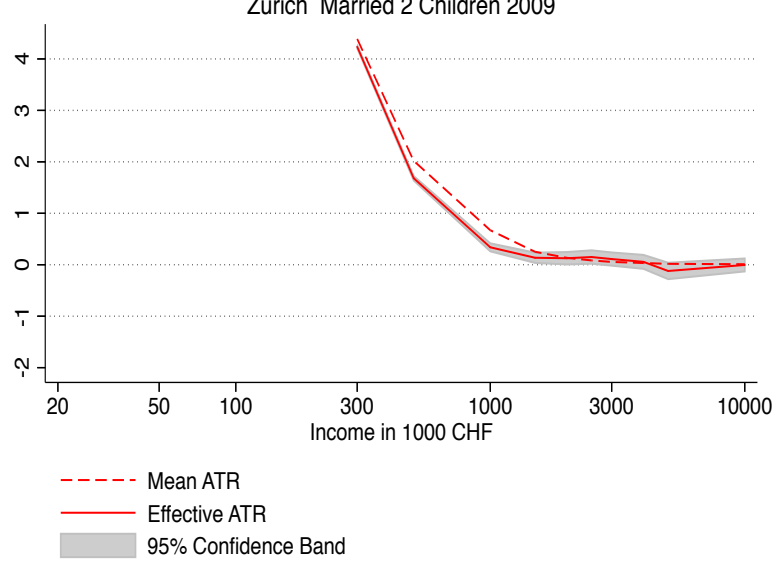

Figure 12: Average tax rate and progressivity of married couples with two children in the Zurich metropolitan area in 2009. 41,857 observations, local polynomial regression (order 3) with Epanechnikov kernel and half-log-bandwidth 0.461. Change in average rate progression multiplied by 100,000 .

percentage points for an income of 10M. CHF, which generates large potential gains of moving to the lower tax municipalities. The mean average tax rate is comparably high, which is due to the large population and high taxation in the city of Zurich. The effective average tax rate starts being significantly lower than this benchmark as of an income of 200,000 CHF. This gap increases to about 15 percentage points for incomes above 3M. CHF. As of an income of 1M. CHF the effective average tax rate starts declining, continuing to an income of 3M. CHF. The progressivity is also significantly lower and in this case even negative for incomes between $1 \mathrm{M}$. CHF and $2 \mathrm{M}$. CHF, as panel $\mathrm{B}$ of Figure 10 indicates.

For married couples without children the picture looks similar. However, there is no range of income where our estimates of the progressivity are significantly negative (see Figure 11). For families with children the the difference between the effective and the mean average tax rate is again smaller. This is consistent with our explanation from above that families with children differ substantially in their location preferences from the other household types.

Hence, we have shown that the results also hold for smaller functional urban areas and are not driven by cultural or structural differences between different regions of Switzerland.

\subsection{Historic Development}

Our proposed measure of effective country-wide average and marginal tax rates also allows us to study the evolution of effective country-wide average tax rates since 1975. Figure 13 presents the results for a married couple without children in 1975. The spread between the municipality with the highest and the lowest average tax rate was about $32 \%$ points 

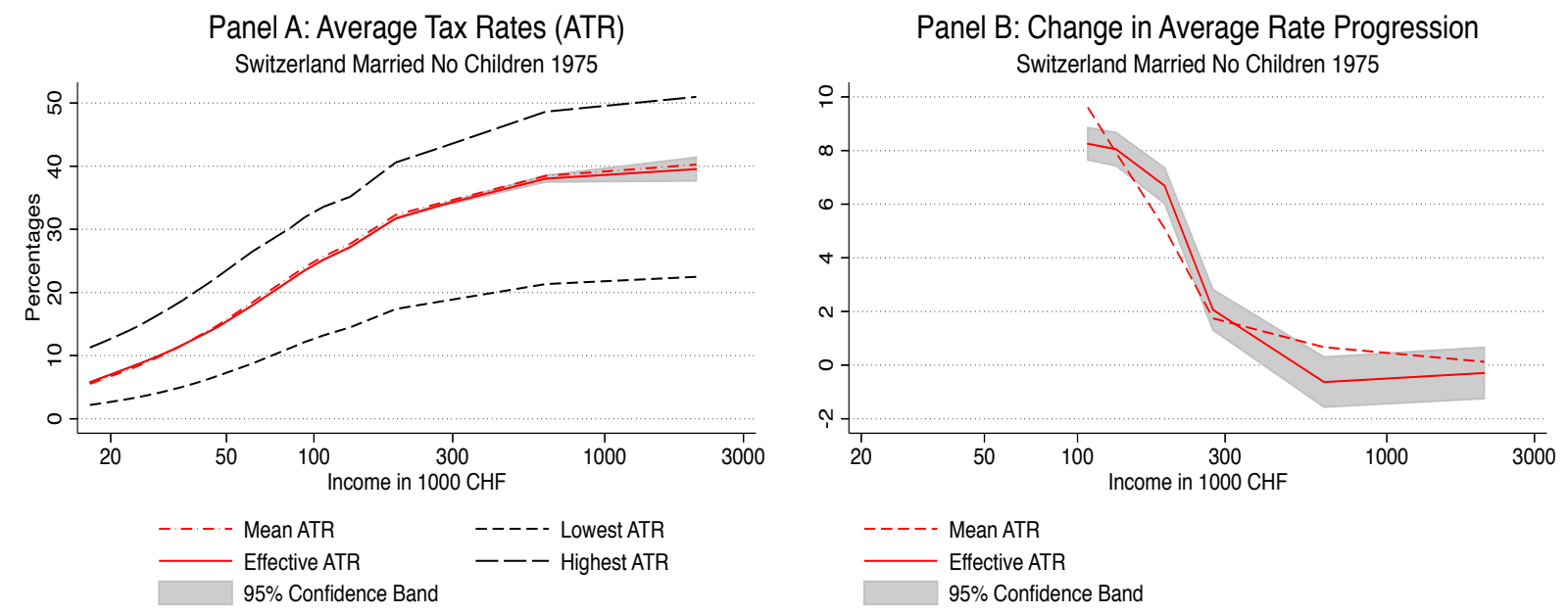

Figure 13: Country-wide average tax rate and progressivity of married couples without children in 1975. 380,069 observations, local polynomial regression (order 1) with Epanechnikov kernel and half-log-bandwidth 0.072 . Change in average rate progression multiplied by 100,000 .

for top incomes in 1975 and thus even more pronounced than in 2009 (see Figure 5). So in principle, high income tax rates could have been avoided by locating in low-tax municipalities. However, there was basically no difference between the effective average tax rate and the mean average tax rate in 1975. Hence, high-income households did not systematically locate differently than low-income households as in 2009. The progressivity reducing effect from systematic income sorting we document for 2009 therefore emerged between 1975 and 2009. Figure 14 shows the evolution of the difference between the mean average tax rate and the effective average tax rate for taxpayers with median, top$10 \%$, top- $1 \%$ and top- $0.1 \%$ income, respectively. At the median, the effective average tax rate and the mean average tax rate are always equal and the level of taxation is fairly stable over time. The effective average tax rate for the top- $10 \%$ is always around one percentage point lower than the mean average tax rate. Both increase until the mideighties and decline thereafter. For taxpayers with incomes in the top-1\%, the effective average tax rate is lower than the mean average tax rate around 1980, and as of 1990 the difference constantly increases up to 2 percentage points in 2009. This decline is even stronger for the top incomes (top-0.1\%). While there was basically no difference between the effective average tax rate and the mean average tax rate until 1990, the difference increases to 3.9 percentage points until 2009. Figure 14 shows that the effective tax burden declined by 8.1 percentage points between 1975 and 2009; 57\% of this decline was due to reductions in statutory tax rates and $43 \%$ to stronger income sorting of the population. The overall picture implies that the sorting of high income households into low-tax municipalities increased over time. This is likely due to an increased mobility of taxpayers, as suggested by recent literature on tax-induced mobility of high income taxpayers (see e.g. Schmidheiny 2006a, Kleven et al. 2013, Moretti and Wilson 2015, or 

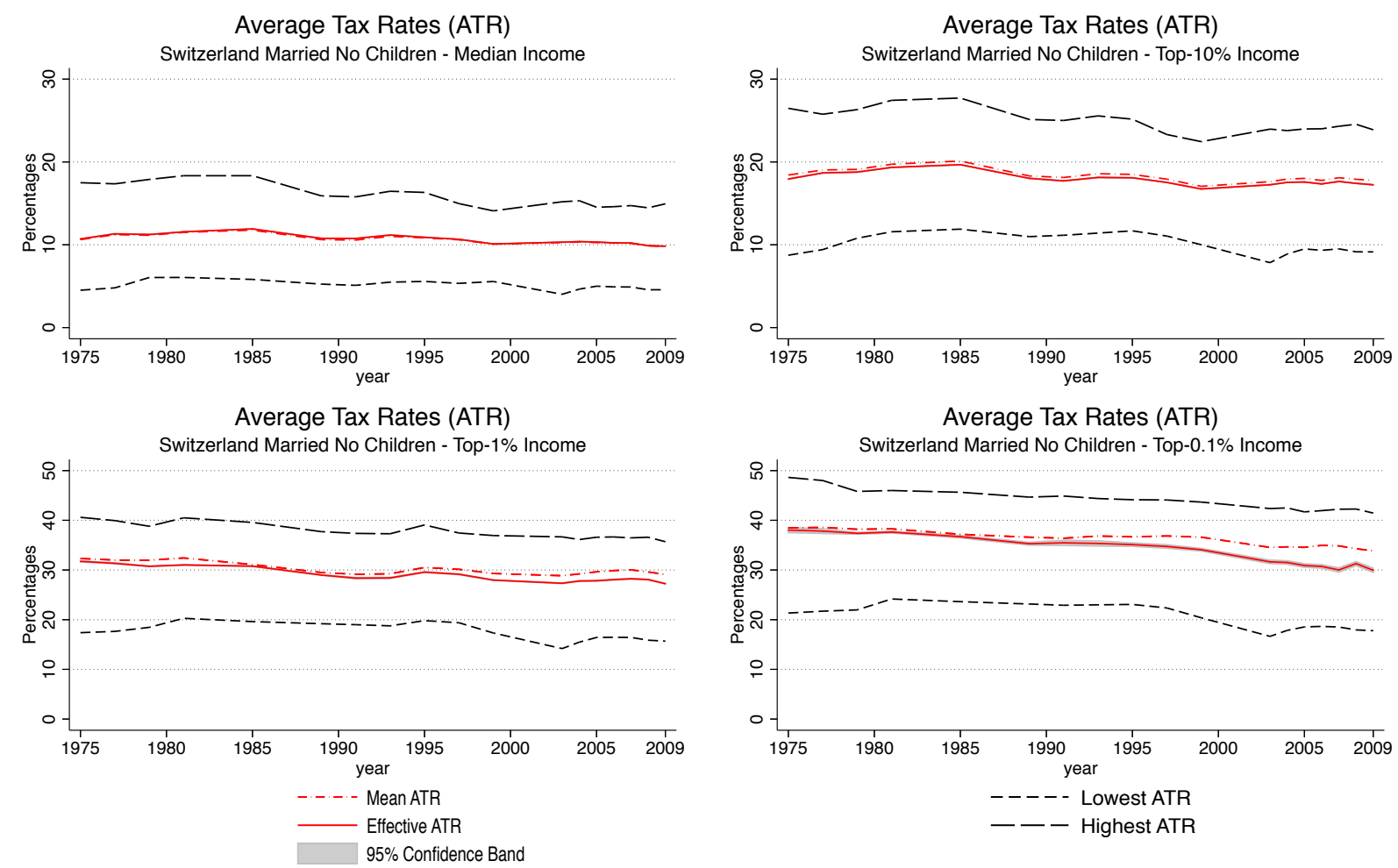

Figure 14: Country-wide average tax rates for the median, the top- $10 \%$, the top- $1 \%$ and the the top- $0.1 \%$ income tax payers. The percentiles' equivalents in CHF are presented in Table 8 in appendix D.

Akcigit et al. 2015).

Time series of the country-wide effective average and marginal tax rates for the 50th, the 75th, 90th, 99th and 99.9th income percentiles are reported in Tables 6 and 7, respectively, in appendix D. Table 8 also gives the nominal values of the respective income percentiles in $\mathrm{CHF}$.

\section{Considering Housing Price Capitalization}

In spatial equilibrium, low local tax rates should capitalize into high local housing prices. The benefits from lower tax rates are (at least partly) offset by higher local prices (Basten et al., 2014; Morger, 2013; Schmidheiny, 2006a). Figure 15 shows the strong negative relationship of rents and taxation in the metropolitan area of Zurich. The solid red line represents the fitted values of a simple OLS regression of the rents on the tax rates. The coefficient estimate is -1.61 and highly significant $(\mathrm{p}<0.001)$.

Our measure of the effective average tax rate in a fiscally decentralized country does not account for differences in real income due to such housing price differences. From the perspective of the state, this is the relevant measure, as it measures the degree to which households contribute to the common good. However, from the perspective of individual households, we should also account for the additional burden paid indirectly through 


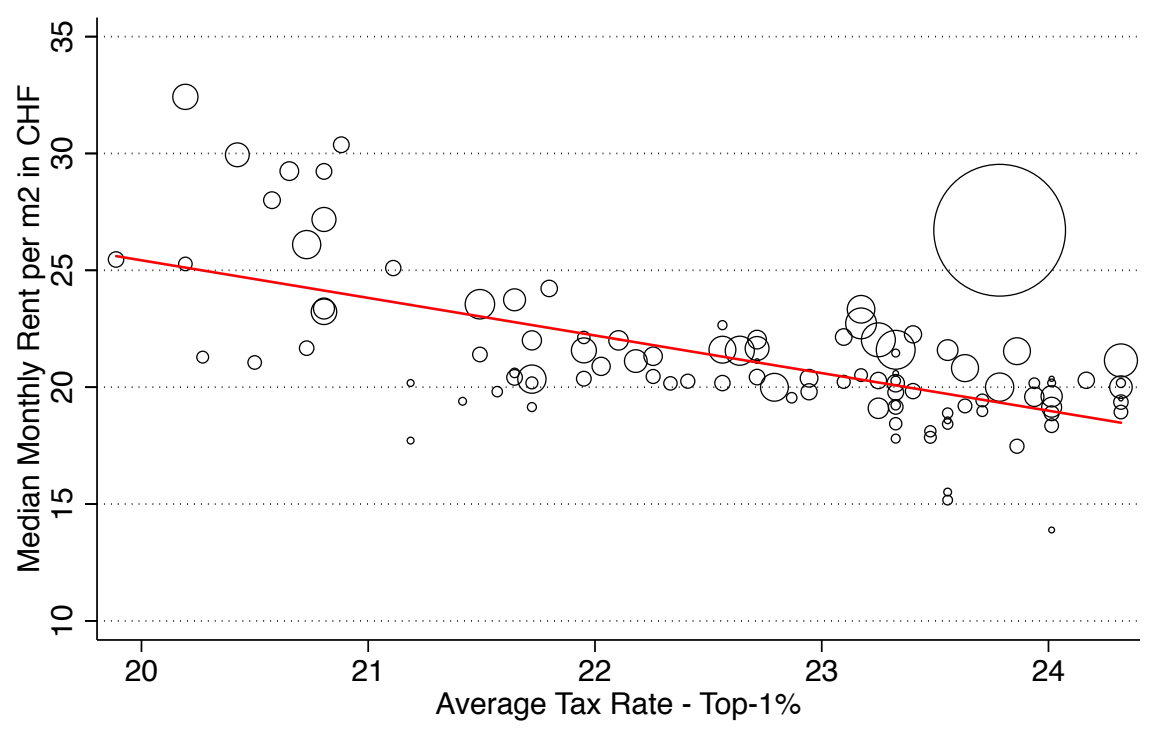

Figure 15: Median monthly rent per square meter and average tax rate for an unmarried taxpayer with top $1 \%$ income in all municipalities of the Zurich metropolitan area. The size of the markers reflects the population size of the municipality.

house prices.

The household perspective is the motive behind the concept of the residual income progression discussed in section 2 . This concept allows us to naturally account for the disutility of higher local housing prices. We propose the following new measure: equivalent residual income progression. The basic idea behind this measure is to compare residual utility instead of residual income. Residual utility accounts for both different tax rates and different local prices. However, using an ordinal concept, utility is only identified up to a monotone transformation. Measuring the progressivity of residual utility would depend on some arbitrary transformation. We therefore use the utility function to calculate an equivalent income that a household would need to obtain in a reference municipality in order to be indifferent to its actual place of residence. This is similar in spirit to the concept of the equivalent variation used for policy evaluations in microeconomics.

Consider a larger geographic area that is divided into jurisdictions $j=1, \ldots, J$. A household $i$ maximises his utility over a bundle of goods $x$ and housing $h$ subject to its budget constraint:

$$
\begin{array}{r}
\max _{x, h} U(h, x)=h^{\alpha} x^{(1-\alpha)} \\
\text { s.t. }\left[1-A T R_{j}(y)\right] y \geq p x+r_{j} h
\end{array}
$$

Where the $p$ and $r$ denote the price vector of all other goods and housing respectively. Note that the price vector $p$ is independent of the residential jurisdiction $j$. This is a reasonable assumption within a metropolitan area, where prices of mobile goods should not vary 
across jurisdictions. Also the nominal income is exogenous in this model. Considering a metropolitan area this is a reasonable assumption but likely not for a whole country, where the occupation choice might influence the set of possible location choices. Hence, we can apply our measure only to metropolitan areas where it is reasonable to assume that people with an occupation in the metropolitan area will choose their residential jurisdictions amongst the jurisdictions in the metropolitan area without having to change their occupation.

Solving this model, it is easy to show that the indirect utility of an individual with income $y$ living in jurisdiction $j$ is:

$$
V_{j}(y)=\left[(1-\alpha) \frac{1}{p}\right]^{(1-\alpha)}\left[\alpha \frac{1}{r_{j}}\right]^{\alpha}\left[1-A T R_{j}(y)\right] y
$$

Let the residual income be denoted as: $R_{j}(y)=\left[1-A T R_{j}(y)\right] y$. Then we can rewrite the indirect utility as:

$$
V_{j}(y)=\gamma\left[\frac{1}{r_{j}}\right]^{\alpha} R_{j}(y)
$$

The equivalent residual income $R^{e}$ in the main city $m$ as reference location gives the residual income that an individual with income $y$ would need to earn in the main city of the metropolitan area to gain the same utility as in his residential jurisdiction $j$.

$$
\begin{aligned}
{\left[\frac{1}{r_{m}}\right]^{\alpha} R^{e} } & =\left[\frac{1}{r_{j}}\right]^{\alpha} R_{j}(y) \\
R^{e} & =\left[\frac{r_{m}}{r_{j}}\right]^{\alpha} R_{j}(y)
\end{aligned}
$$

Thus, we have a measure that enables us to compare real net-of-tax incomes within a metropolitan area and therefore we can also calculate the progressivity of the tax system in terms of real net-of-tax income. All we need in addition is the relative amount of residual income spent on housing $\alpha$ and the housing prices in the jurisdictions.

In Switzerland, the share of residual income spent on housing is $21 \% .{ }^{15}$ The housing prices are median rents per square meter in 2009 of the single municipalities. ${ }^{16}$

We first present estimates of the residual income progression for the Zurich area without accounting for housing price differences: The left part of Figure 16 depicts the effective residual income progression in the metropolitan area of Zurich. Due to the consistency with the change in average tax progression, we should get the same classification into progressive and regressive parts of the income range. This is indeed the case: for incomes between 1 and $2.5 \mathrm{M}$. CHF the income tax system is regressive. The right part of

\footnotetext{
${ }^{15}$ Source: Bundesamt für Statistik Haushaltshaltsbudgeterhebung 2011

${ }^{16}$ Source: Rent prices from the housing advertisements of all major Swiss online housing rental platforms
} 
Residual Income Progression

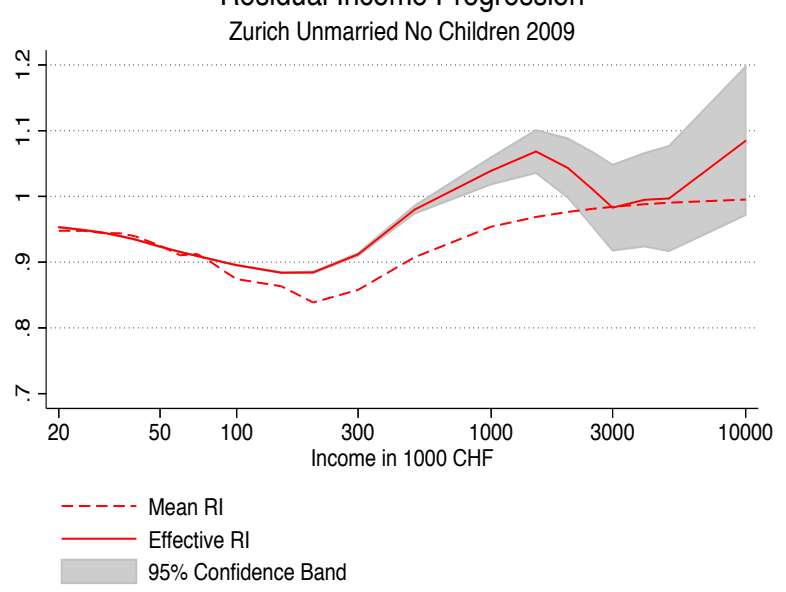

Residual Income Progression

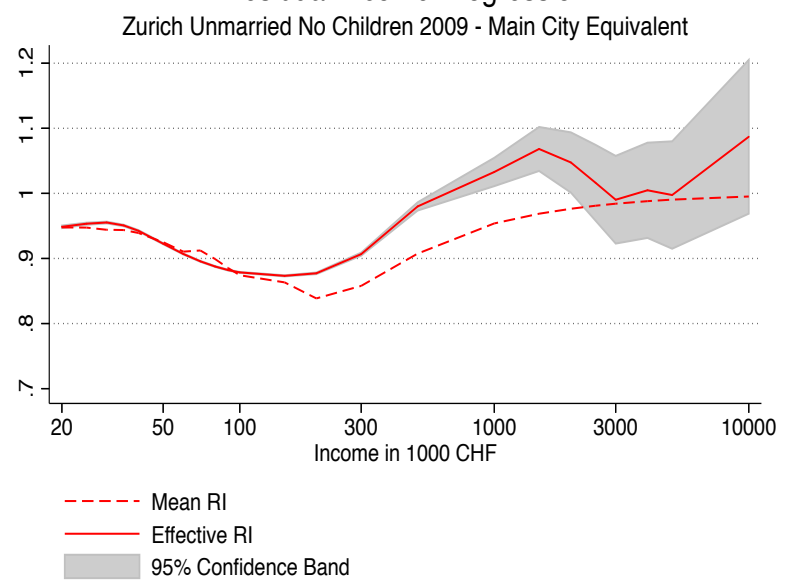

Figure 16: Residual income progression of unmarried taxpayers without children in the Zurich metropolitan area in 2009. 286,831 observations, local polynomial regression (order 3) with Epanechnikov kernel and half-log-bandwidth 0.459.

Figure 16 shows the same measures for the equivalent residual income progression, i.e. accounting for the disutility of local housing prices. There are no remarkable changes if we account for housing price differences in the Zurich metropolitan area. The regressivity survives for the respective income range. Consequently, those people not only contribute relatively less to the public good but also suffer relatively less in terms of their utility. Thus, for the range of 1 up to $2.5 \mathrm{M}$. CHF we have a redistribution of utility to higher incomes. Furthermore, these findings show that the low tax rates do not capitalize into high housing prices for those very high income people. This is in line with the results of Morger (2013), who also shows that the capitalization of tax differentials into housing prices is far from $100 \%$ in Switzerland.

\section{Conclusion}

We propose a set of measures that allows us to quantify the overall level and the progressivity of tax systems in a fiscally decentralized country. We define two measures for the level of taxation: the effective average tax rate and the effective marginal tax rate. Additionally, we define three progressivity measures: the country-wide change in average rate progression, country-wide liability progression, and the country-wide residual income progression. All our measures take the relative size of the jurisdictions and potential income sorting into account. Furthermore, we provide an estimation strategy for our measures together with a benchmark that allows determining the role of systematic income sorting.

Exploiting the universe of Swiss income taxpayers, we find high income households face lower tax rates than in the benchmark case. This is because high income households sort systematically into low tax municipalities. The same holds for effective progressivity. 
The direction of this effect is robust across different household types but its size varies. For families with two children, the difference between the effective tax rates and the benchmark is fairly small. In contrast, for married couples without children, we even find a regressive part of the income tax system for very high incomes. Our results also hold within metropolitan areas.

Historically, the size of the effect has increased over time which is likely due to the higher mobility of taxpayers. The proposed measure of the effective average and marginal tax rates also allows us to adequately describe the evolution of the country-wide tax burden over time. We document that about half of the reduction in the tax burden on top incomes between 1975 and 2009 is due to reductions in statutory tax rates and about half due to stronger income sorting of the population. Accounting for housing price capitalization does not alter our results.

The contribution of this paper is twofold: first, it contributes to the basic taxation literature by providing a consistent set of measures that allow quantification of the effective tax rates and the effective progressivity of decentralized tax systems both in the cross-section and over time. Second, it contributes to the empirical literature on income segregation, showing that systematic income sorting leads to lower effective tax rates and to a lower effective progressivity of the income tax system for high income households in Switzerland. 


\section{References}

Akcigit, U., S. Baslandze, and S. Stantcheva (2015). Taxation and the international mobility of inventors. Technical report, National Bureau of Economic Research.

Atkinson, A. B. (1970). On the measurement of inequality. Journal of economic theory $2(3), 244-263$.

Basten, C. C., M. Von Ehrlich, and A. Lassmann (2014). Income taxes, sorting, and the costs of housing: Evidence from municipal boundaries in switzerland.

Bayer, P., F. Ferreira, and R. McMillan (2007). A unified framework for measuring preferences for schools and neighborhoods. Journal of Political Economy 115(4), 588638.

Bayer, P. and R. McMillan (2012). Tiebout sorting and neighborhood stratification. Journal of Public Economics 96(11), 1129-1143.

Black, S. E. (1999). Do better schools matter? parental valuation of elementary education. Quarterly journal of economics, 577-599.

Boadway, R. and M. Keen (2000). Redistribution. Handbook of income Distribution 1, 677-789.

Brülhart, M., S. Bucovetsky, and K. Schmidheiny (2015). Taxes in cities: Interedependence, asymmetrey and agglomeration. Handbook of Regional and Urban Economics 5.

Calabrese, S., D. Epple, and R. Romano (2007). On the political economy of zoning. Journal of Public Economics 91(1), 25-49.

Calabrese, S. M., D. N. Epple, and R. E. Romano (2012). Inefficiencies from metropolitan political and fiscal decentralization: Failures of tiebout competition. The Review of Economic Studies 79(3), 1081-1111.

Conesa, J. C. and D. Krueger (2006). On the optimal progressivity of the income tax code. Journal of Monetary Economics 53(7), 1425-1450.

Epple, D., R. Filimon, and T. Romer (1984). Equilibrium among local jurisdictions: Toward an integrated treatment of voting and residential choice. Journal of public economics $24(3), 281-308$.

Epple, D. and T. Nechyba (2004). Fiscal decentralization. Handbook of regional and urban economics 4, 2423-2480. 
Epple, D. and G. J. Platt (1998). Equilibrium and local redistribution in an urban economy when households differ in both preferences and incomes. Journal of Urban Economics 43(1), 23-51.

Epple, D., R. Romano, and H. Sieg (2012). The intergenerational conflict over the provision of public education. Journal of Public Economics 96(3), 255-268.

Epple, D. and T. Romer (1991). Mobility and redistribution. Journal of Political economy, 828-858.

Epple, D. and H. Sieg (1999). Estimating equilibrium models of local jurisdictions. Journal of Political Economy 107(4), 645-681.

Fan, J. and I. Gijbels (1996). Local polynomial modelling and its applications. Chapman, Hall, London.

Fullerton, D. (1984). Which effective tax rate? National Tax Journal, 23-41.

Goodspeed, T. J. (1989). A re-examination of the use of ability to pay taxes by local governments. Journal of Public Economics 38(3), 319-342.

Gouveia, M. and R. P. Strauss (1994). Effective federal individual income tax functions: An exploratory empirical analysis. National Tax Journal, 317-339.

Gravel, N. and R. Oddou (2014). The segregative properties of endogenous jurisdiction formation with a land market. Journal of Public Economics 117, 15-27.

Gruber, J. and E. Saez (2002). The elasticity of taxable income: evidence and implications. Journal of public Economics 84(1), 1-32.

Hodler, R. and K. Schmidheiny (2006). How fiscal decentralization flattens progressive taxes. FinanzArchiv: Public Finance Analysis 62(2), 281-304.

Jakobsson, U. (1976). On the measurement of the degree of progression. Journal of public economics 5(1), 161-168.

Kleven, H. J., C. Landais, E. Saez, and E. A. Schultz (2013). Migration and wage effects of taxing top earners: evidence from the foreigners' tax scheme in denmark. Technical report, National Bureau of Economic Research.

Mendoza, E. G., A. Razin, and L. L. Tesar (1994). Effective tax rates in macroeconomics: Cross-country estimates of tax rates on factor incomes and consumption. Journal of Monetary Economics 34(3), 297-323. 
Mirrlees, J. A. (1971). An exploration in the theory of optimum income taxation. The review of economic studies, 175-208.

Moretti, E. and D. Wilson (2015). The effect of state taxes on the geographical location of top earners: evidence from star scientists. Technical report, National Bureau of Economic Research.

Morger, M. (2013). Heterogeneity in income tax capitalization and its effects on segregation within switzerland. Arbeitspapiere - Eidgenössische Steuerverwaltung.

Musgrave, R. A. and T. Thin (1948). Income tax progression, 1929-48. The Journal of Political Economy 56(6), 498-514.

Oates, W. E. (1969). The effects of property taxes and local public spending on property values: An empirical study of tax capitalization and the tiebout hypothesis. The Journal of Political Economy, 957-971.

Parchet, R. (2014). Are local tax rates strategic complements or strategic substitutes? IdEP Economic Papers 2014/07.

Pigou, A. C. (1951). A study in public finance. London: Macmillan.

Ross, S. and J. Yinger (1999). Sorting and voting: A review of the literature on urban public finance. Handbook of regional and urban economics 3, 2001-2060.

Rothschild, M. and J. E. Stiglitz (1973). Some further results on the measurement of inequality. Journal of Economic Theory 6(2), 188-204.

Saez, E. (2001). Using elasticities to derive optimal income tax rates. Review of Economic Studies 68(1), 205-29.

Saez, E., J. Slemrod, and S. H. Giertz (2012). The elasticity of taxable income with respect to marginal tax rates: A critical review. Journal of Economic Literature, 3-50.

Schaltegger, C. A., F. Somogyi, and J.-E. Sturm (2011). Tax competition and income sorting: Evidence from the zurich metropolitan area. European Journal of Political Economy 27(3), 455-470.

Schmidheiny, K. (2006a). Income segregation and local progressive taxation: Empirical evidence from Switzerland. Journal of Public Economics 90(3), 429-458.

Schmidheiny, K. (2006b). Income segregation from local income taxation when households differ in both preferences and incomes. Regional Science and Urban Economics 36(2), 270-299. 
Slitor, R. E. (1948). The measurement of progressivity and built-in flexibility. The Quarterly Journal of Economics 62(2), 309-313.

Tiebout, C. M. (1956). A pure theory of local expenditures. The journal of political economy, 416-424.

Westhoff, F. (1977). Existence of equilibria in economies with a local public good. Journal of economic Theory 14(1), 84-112. 


\section{Appendix}

\section{A Theoretical Model}

We build upon the model of Schmidheiny (2006a), except that we relax some assumptions made on the tax schedule. Instead of assuming that the tax functions in both jurisdictions are a multiple of each other, we only assume that the tax functions in both jurisdictions do not cross, i.e. the order of jurisdictions with respect to the level of taxation is perfect and consistent over gross income and that higher tax rates imply higher progressivity.

There are two jurisdictions $j=1,2$ with different progressive tax functions $A T R_{j}(y)$ : $\partial A T R_{j}(y) / \partial y>0 \forall y$. Without loss of generality we assume that $A T R_{1}(y)>A T R_{2}(y)$ and $\partial A T R_{1}(y) / \partial y>\partial A T R_{2}(y) / \partial y$ for all $y$. The economy consists of three goods: housing, private consumption, and a local public good. There is a continuum of households that differ in income $y \in[\underline{y}, \bar{y}]$ and their taste for housing. Hodler and Schmidheiny (2006) show that in the equilibrium of this model the probability of a household with gross income $y$ living in jurisdiction $1, P(1 \mid y)$, is weakly decreasing for all $y$ and strictly for some $y$. Thus, high income people are more likely to live in the low tax jurisdiction. This is the primary result we build on.

As defined above, the effective average tax rate $A T R(y)$ is then given as:

$$
\begin{aligned}
\operatorname{ATR}(y) & =\sum_{j=1}^{2} P(j \mid y) A T R_{j}(y) \\
& =P(1 \mid y) A T R_{1}(y)+[1-P(1 \mid y)] A T R_{2}(y)
\end{aligned}
$$

And the mean average tax rate is:

$$
\operatorname{MATR}(y)=\sum_{j=1}^{2} P(j) A T R_{j}(y)
$$

Let the difference of both level measures be denote as:

$$
\begin{aligned}
\Delta(y) & =\operatorname{ATR}(y)-\operatorname{MATR}(y) \\
& =[P(1 \mid y)-P(1)]\left[A T R_{1}(y)-A T R_{2}(y)\right]
\end{aligned}
$$

Then we can derive the following proposition:

Proposition 1. If both jurisdictions are populated and if the housing prices $p_{j}$ differ and the tax rates in jurisdiction 1 are strictly larger than in jurisdiction 2, then there exists a gross income $y^{*}$ such that for all gross incomes below $y^{*}$ the effective average tax rate is higher (strictly higher for some $y$ ) than the mean average tax rate and that for all gross 
incomes above $y^{*}$ the effective average tax rate is lower (strictly lower for some $y$ ) than the mean average tax rate.

Proof: $\left[A T R_{1}(y)-A T R_{2}(y)\right]>0$ by assumption. Further, we know that $P(1 \mid y)$ is decreasing in $y$, therefore $P(1 \mid \underline{y})>P(1 \mid \bar{y})$. Because the unconditional probability is just a weighted integral of the conditional probabilities $P(1)=\int_{\underline{y}}^{\bar{y}} f(y) P(1 \mid y) d y$ while $\int_{\underline{y}}^{\bar{y}} f(y) d y=1$, we know that $P(1 \mid \underline{y})>P(1)>P(1 \mid \bar{y})$. Therefore, $\Delta(\underline{y})>0$ and $\Delta(\bar{y})<0$. From the continuity of $\Delta(y)$ it follows that there must be at least one $y^{*}$, where $\Delta\left(y^{*}\right)=0$. From the fact that $\partial P(1 \mid y) / \partial P(1) \leq 0$ we know that there exists no $y_{3}$ that lies between $y_{1}^{*}$ and $y_{2}^{*}$, both satisfying $\Delta\left(y_{1}^{*}\right)=\Delta\left(y_{2}^{*}\right)=0$ that satisfies $\Delta\left(y_{3}\right) \neq 0$.

Thus, our model predicts that the effective average tax rate of low income people is higher than the mean average tax rate, while it is lower for people with high incomes.

In this two-jurisdiction model we can write the effective marginal tax rate as:

$$
\begin{aligned}
\operatorname{MTR}(y) & =\frac{\partial T(y)}{\partial y}=\frac{\partial E\left\{T_{j}(y) \mid y\right\}}{\partial y} \\
& =\underbrace{\frac{\partial P(1 \mid y)}{\partial y}\left[T_{1}(y)-T_{2}(y)\right]}_{\leq 0}+\underbrace{P(1 \mid y) \frac{\partial T_{1}(y)}{\partial y}+[1-P(1 \mid y)] \frac{\partial T_{2}(y)}{\partial y}}_{E\left\{\partial T_{j} / \partial y \mid y\right\}}
\end{aligned}
$$

From equation 32 it follows directly that the effective marginal tax rate is even lower than a weighted mean of the local marginal tax rates that takes the income sorting into account $E\left\{\partial T_{j} / \partial y \mid y\right\}$.

The mean marginal tax rate is:

$$
\begin{aligned}
\operatorname{MMTR}(y) & =\frac{\partial M T(y)}{\partial y} \\
& =P(1) \frac{\partial T_{1}(y)}{\partial y}+[1-P(1)] \frac{\partial T_{2}(y)}{\partial y}
\end{aligned}
$$

Let the difference of both denote as $D(y)$ :

$$
\begin{aligned}
D(y) & =\operatorname{MTR}(y)-\operatorname{MMTR}(y) \\
& =\underbrace{\frac{\partial P(1 \mid y)}{\partial y}\left[T_{1}(y)-T_{2}(y)\right]}_{\leq 0}+[P(1 \mid y)-P(1)] \underbrace{\left[\frac{\partial T_{1}(y)}{\partial y}-\frac{\partial T_{2}(y)}{\partial y}\right]}_{\leq 0}
\end{aligned}
$$

Proposition 2. If both jurisdictions are populated and if the housing prices $p_{j}$ differ and the tax rates in jurisdiction 1 are strictly larger than in jurisdiction 2, then there exists a gross income $y^{* *}$ such that for all gross incomes above $y^{* *}$ the effective marginal tax rate is lower (strictly lower for some $y$ ) than the mean marginal tax rate.

Proof: The proof directly follows as a corollary from proposition 1 and the negativity of 
the first addend.

Thus, we can show that in this two-jurisdiction model the effective marginal tax rate is also lower than the mean marginal tax rate for high incomes. Note that we cannot make a general statement about the relationship for incomes lower than $y^{* *}$.

Beyond the level predictions our model also has some interesting implications for the progressivity of the tax system:

$$
\begin{aligned}
\frac{\partial A T R(y)}{\partial y} & =\sum_{j=1}^{2} \frac{\partial P(j \mid y)}{\partial y} A T R_{j}(y)+\sum_{j=1}^{2} P(j \mid y) \frac{\partial A T R_{j}(y)}{\partial y} \\
& =\underbrace{\frac{\partial P(1 \mid y)}{\partial y}\left[A T R_{1}(y)-A T R_{2}(y)\right]}_{\leq 0}+\underbrace{P(1 \mid y) \frac{\partial A T R_{1}(y)}{\partial y}+[1-P(1 \mid y)] \frac{\partial A T R_{2}(y)}{\partial y}}_{E\left\{\partial A T R_{j}(y) / \partial y\right\}}
\end{aligned}
$$

Because $\partial P(1 \mid y) / \partial y<0$ and $A T R_{1}(y)-A T R_{2}(y)>0$, the first addend is negative. The second addend is the expected value of the local change in average rate progression, taking the income sorting into account. Therefore, without making any further assumption about the relation between the tax level and the progressivity, we can conclude, that the change in average rate progression of the income tax system is lower than the expected value of the local average progression.

If a higher tax rate implies a higher change in average rate progression like in our model $^{17}$ of Hodler and Schmidheiny (2006), we can derive the following relationship: Let the change in average rate progression of the mean average tax rate be:

$$
\frac{\partial M A T R(y)}{\partial y}=\sum_{j=1}^{2} P(j) \frac{\partial A T R_{j}(y)}{\partial y}=P(1) \frac{\partial A T R_{1}(y)}{\partial y}+[1-P(1)] \frac{\partial A T R_{2}(y)}{\partial y}
$$

Then the difference in these progressivity measures is:

$$
\delta(y)=\underbrace{\frac{\partial P(1 \mid y)}{\partial y}\left[A T R_{1}(y)-A T R_{2}(y)\right.}_{\leq 0}]+[P(1 \mid y)-P(1)]\left[\frac{\partial A T R_{1}(y)}{\partial y}-\frac{\partial A T R_{2}(y)}{\partial y}\right]
$$

Proposition 3. If both jurisdictions are populated and if the housing prices $p_{j}$ differ and the tax rates in jurisdiction 1 are strictly larger than in jurisdiction 2, then there exists a gross income $y^{* * *}$ such that for all gross incomes above $y^{* * *}$ the effective progressivity is lower (strictly lower for some $y$ ) than the progressivity of the mean average tax rate.

Proof: The proof directly follows as a corollary from proposition 1 , the fact that $\partial A T R_{1}(y) / \partial y>$

\footnotetext{
${ }^{17}$ This is the case in Switzerland for the local taxes within a canton.
} 
$\partial A T R_{2}(y) / \partial y$, and the negativity of the first addend.

Therefore, the two jurisdiction-model not only implies that the level of the effective average tax rate is below the mean average tax rate for high incomes but also that its progressivity is lower than that of the benchmark. For low incomes we cannot derive a similar statement.

\section{B Consistency Proof of Progressivity Measures}

Liability Progression For strictly positive income, $y>0$, and strictly positive average tax rates, $\operatorname{ATR}(y)>0$, the liability progression and the change in average rate progression are consistent in their classification of tax schedules into regressive or progressive. Proof:

$$
\begin{gathered}
\frac{\partial T(y)}{\partial y} \frac{y}{T(y)}>1 \\
\left(\frac{\partial A T R(y)}{\partial y} y+A T R(y)\right) \frac{1}{A T R(y)}>1 \\
\frac{\partial A T R(y)}{\partial y} \frac{y}{A T R(y)}>0 \\
\frac{\partial A T R(y)}{\partial y}>0
\end{gathered}
$$

Residual Income Progression For strictly positive income, $y>0$, and strictly positive average tax rates, $\operatorname{ATR}(y)>0$, and average tax rates of less than $100 \%, \operatorname{ATR}(y)<1$, the residual income progression and the change in average rate progression are consistent in their classification of tax schedules into regressive or progressive. Proof:

$$
\begin{gathered}
\frac{\partial[y-T(y)]}{\partial y} \frac{y}{[y-T(y)]}<1 \\
\left(1-\frac{\partial A T R(y)}{\partial y} y-A T R(y)\right) \frac{1}{1-A T R(y)}<1 \\
\frac{\partial A T R(y)}{\partial y} \frac{y}{1-A T R(y)}>0 \\
\frac{\partial A T R(y)}{\partial y}>0
\end{gathered}
$$

Thus, all three progressivity measures are consistent in their classification of tax schedules into regressive or progressive under regular conditions. 


\section{Data}

\section{C.1 Gross Income}

Because we only observe the taxable income and the average tax rates are defined in terms of the gross income, we need to reconstruct the gross income of all Swiss taxpayers. The annual publication of the Swiss Federal Tax Administration also contains average tax rates on the federal level $A T R^{f}(y)$. From this, we calculate the tax liabilities at all published income levels:

$$
T_{f}(y)=A T R_{f}(y) y
$$

For all household types we can calculate the implicit deductions by comparing this tax liability with the statutory tax liability. The statutory $\operatorname{tax}^{18}$ liability $S(z)$ is defined over the taxable income $z=y-d$. Because the deductions $d$ are the only unknown in the following equation, we can reconstruct the assumed deductions of the Swiss Federal Tax Administration for the respective household type with gross income $y$.

$$
\begin{gathered}
T_{f}(y)=S\left(y^{t}\right)=S(y-d) \\
d(y)=y-S^{-1}\left(T_{f}(y)\right)
\end{gathered}
$$

It turns out that the relationship between the deductions and the gross income that the ESTV assumed can be very well approximated by a linear relationship:

$$
d=a+b y
$$

After calculating all deductions for the income levels for both household types separately, we regress the the implicit deduction on the gross income levels. Table 5 represents the results. Singles are assumed to deduct a fixed amount of 4,679 CHF, couples to deduct

\begin{tabular}{|c|c|c|c|}
\hline & $\begin{array}{l}\text { Unmarried } \\
\text { No Children }\end{array}$ & $\begin{array}{l}\text { Married Couple } \\
\text { No Children }\end{array}$ & $\begin{array}{c}\text { Married Couple } \\
2 \text { Children }\end{array}$ \\
\hline Fixed amount & 4,679 & 9,063 & 22,912 \\
\hline Fraction of income & $10.32 \%$ & $10.32 \%$ & $10.36 \%$ \\
\hline
\end{tabular}
9,063 CHF, and families 22,912 CHF. Additionally, all household types are assumed to deduct $10 \%$ of their gross income.

Table 5: Deductions.

Note that calculating the deductions this way does not impose any further assumptions on

\footnotetext{
${ }^{18}$ Swiss Federal Tax Administration: Table for calculation of the federal income tax of natural persons (Art. $214 \mathrm{DBG})$
} 
the relationship between gross income and deductions because this relationship is already implied in the data on tax liabilities by the ESTV that we use to calculate the average tax rate data. We also avoid problems that arise because the federal and the cantonal taxable income differ.

Finally, we calculate the individual gross incomes for each individual from the individual taxable income $z_{i}$ as follows:

$$
y_{i}=\frac{z_{i}+a}{1-b}
$$

\section{C.2 Individual Tax Rates}

In a final step, we calculate the individual tax data. For individuals with a gross income below 1,000,000 CHF we interpolate the average tax rates with the average tax rates of the next gross income steps in the residential municipality we have data on. For individuals with a gross income above 1,000,000 CHF, we calculate the average tax rate as follows:

$$
\begin{aligned}
A T R_{i} & =\frac{\theta\left(m_{i}\right)\left(y_{i}-1,000,000\right)+T\left(1,000,000, m_{i}\right)}{y_{i}} \\
\theta\left(m_{i}\right) & =\frac{T\left(1,000,000, m_{i}\right)-T\left(500,000, m_{i}\right)}{500,000}
\end{aligned}
$$

This method assumes that the maximum marginal tax rate $\theta(j)$ is already reached at a gross income of 500,000 CHF. This assumption holds exactly for 21 cantons and is a very close approximation for the remaining 5 . Furthermore, the deductions must grow linearly with the gross income which is already assumed in the average tax rate data. 


\section{Time Series}

Table 6: Effective average tax rates at income percentiles for a married couple without children.

\begin{tabular}{rrrrrr}
\hline \hline & \multicolumn{5}{c}{ Percentile } \\
\cline { 2 - 5 } Year & Median & Top-25\% & Top-10\% & Top-1\% & Top-0.1\% \\
\hline 1975 & 10.71 & 13.66 & 17.94 & 31.73 & 38.03 \\
1977 & 11.32 & 14.45 & 18.68 & 31.34 & 37.82 \\
1979 & 11.24 & 14.55 & 18.78 & 30.74 & 37.38 \\
1981 & 11.56 & 15.03 & 19.34 & 31.01 & 37.62 \\
1985 & 11.91 & 15.31 & 19.67 & 30.77 & 36.70 \\
1989 & 10.77 & 13.87 & 18.02 & 28.99 & 35.29 \\
1991 & 10.76 & 13.64 & 17.71 & 28.36 & 35.46 \\
1993 & 11.17 & 14.06 & 18.13 & 28.40 & 35.34 \\
1995 & 10.90 & 14.03 & 18.09 & 29.57 & 35.11 \\
1997 & 10.66 & 13.67 & 17.53 & 29.14 & 34.73 \\
1999 & 10.10 & 13.10 & 16.74 & 27.96 & 34.08 \\
2003 & 10.31 & 13.35 & 17.24 & 27.33 & 31.64 \\
2004 & 10.38 & 13.50 & 17.53 & 27.78 & 31.51 \\
2005 & 10.33 & 13.50 & 17.58 & 27.83 & 30.90 \\
2006 & 10.23 & 13.35 & 17.34 & 28.06 & 30.71 \\
2007 & 10.21 & 13.41 & 17.64 & 28.23 & 30.01 \\
2008 & 9.89 & 13.11 & 17.41 & 28.07 & 31.29 \\
2009 & 9.83 & 13.03 & 17.24 & 27.24 & 29.94 \\
\hline
\end{tabular}


Table 7: Effective marginal tax rates at income percentiles for a married couple without children.

\begin{tabular}{rrrrrr}
\hline \hline & \multicolumn{5}{c}{ Percentile } \\
\cline { 2 - 5 } Year & Median & Top-25\% & Top-10\% & Top-1\% & Top-0.1\% \\
\hline 1975 & 19.94 & 23.85 & 31.38 & 43.05 & 37.48 \\
1977 & 21.01 & 25.77 & 31.84 & 43.36 & 40.90 \\
1979 & 20.90 & 26.21 & 32.10 & 42.51 & 40.88 \\
1981 & 21.47 & 26.94 & 32.84 & 40.95 & 40.65 \\
1985 & 21.95 & 27.66 & 32.35 & 35.42 & 36.85 \\
1989 & 20.05 & 24.70 & 30.06 & 37.31 & 38.56 \\
1991 & 19.39 & 23.78 & 30.90 & 37.88 & 38.66 \\
1993 & 20.03 & 24.29 & 31.53 & 39.72 & 39.06 \\
1995 & 20.22 & 24.56 & 31.54 & 37.85 & 38.32 \\
1997 & 19.90 & 23.56 & 30.35 & 38.36 & 37.85 \\
1999 & 19.53 & 22.67 & 29.00 & 36.39 & 33.29 \\
2003 & 19.72 & 23.16 & 29.97 & 34.72 & 34.31 \\
2004 & 19.76 & 23.54 & 30.43 & 34.12 & 35.09 \\
2005 & 19.73 & 23.47 & 30.65 & 32.81 & 32.93 \\
2006 & 19.20 & 22.83 & 29.86 & 33.51 & 30.82 \\
2007 & 19.39 & 23.16 & 30.45 & 32.49 & 25.84 \\
2008 & 18.90 & 22.93 & 30.12 & 32.04 & 32.42 \\
2009 & 18.79 & 22.79 & 29.91 & 30.64 & 30.36 \\
\hline
\end{tabular}

Table 8: Income percentiles of married taxpayers in CHF.

\begin{tabular}{|c|c|c|c|c|c|}
\hline \multirow[b]{2}{*}{ Year } & \multicolumn{5}{|c|}{ Percentile } \\
\hline & Median & Top-25\% & Top-10\% & Top-1\% & Top- $0.1 \%$ \\
\hline 1975 & 31,862 & 42,879 & 61,345 & 191,240 & 626,880 \\
\hline 1977 & 34,989 & 47,221 & 66,519 & 187,682 & 570,046 \\
\hline 1979 & 36,571 & 49,646 & 69,893 & 192,638 & 562,243 \\
\hline 1981 & 39,039 & 53,379 & 75,311 & 204,793 & 593,767 \\
\hline 1985 & 49,590 & 67,187 & 94,688 & 254,427 & 746,078 \\
\hline 1989 & 56,568 & 77,068 & 110,269 & 315,716 & 976,065 \\
\hline 1991 & 62,022 & 84,553 & 120,692 & 340,425 & $1,086,402$ \\
\hline 1993 & 70,044 & 95,173 & 133,705 & 357,302 & $1,110,294$ \\
\hline 1995 & 72,585 & 98,757 & 138,812 & 372,652 & $1,142,565$ \\
\hline 1997 & 72,509 & 98,819 & 138,971 & 369,015 & $1,132,472$ \\
\hline 1999 & 70,564 & 95,845 & 133,480 & 345,336 & $1,084,541$ \\
\hline 2003 & 81,987 & 111,461 & 158,017 & 427,079 & $1,404,411$ \\
\hline 2004 & 82,256 & 112,475 & 160,201 & 439,753 & $1,459,945$ \\
\hline 2005 & 82,787 & 113,575 & 162,769 & 457,043 & $1,534,746$ \\
\hline 2006 & 83,884 & 115,561 & 167,093 & 486,657 & $1,685,607$ \\
\hline 2007 & 85,780 & 118,573 & 173,228 & 522,684 & $1,905,786$ \\
\hline 2008 & 87,183 & 120,753 & 177,745 & 546,462 & $1,956,418$ \\
\hline 2009 & 88,614 & 122,737 & 179,610 & 529,320 & $1,868,278$ \\
\hline
\end{tabular}

